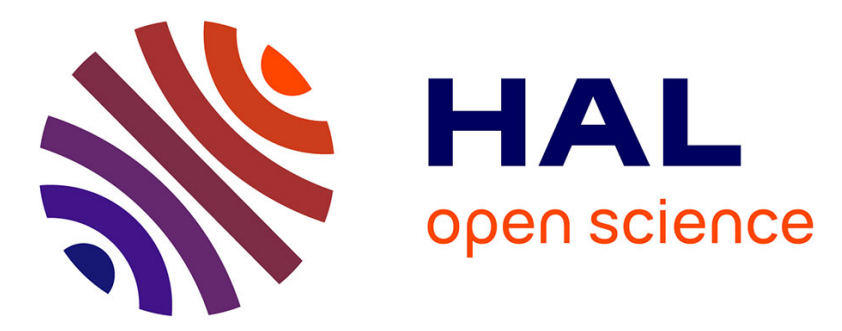

\title{
Crystallographic Statistical Study of Decavanadate Anion Based-Structures: Toward a Prediction of Noncovalent Interactions
}

\author{
N. Bosnjakovic - Pavlovic, Josselin Prevost, A. Spasojevic-De-Biré
}

\section{- To cite this version:}

N. Bosnjakovic - Pavlovic, Josselin Prevost, A. Spasojevic-De-Biré. Crystallographic Statistical Study of Decavanadate Anion Based-Structures: Toward a Prediction of Noncovalent Interactions. Crystal Growth \& Design, 2011, 11 (9), pp.3778-3789. 10.1021/cg200236d . hal-00633676

\section{HAL Id: hal-00633676 \\ https://hal.science/hal-00633676}

Submitted on 24 Sep 2020

HAL is a multi-disciplinary open access archive for the deposit and dissemination of scientific research documents, whether they are published or not. The documents may come from teaching and research institutions in France or abroad, or from public or private research centers.
L'archive ouverte pluridisciplinaire HAL, est destinée au dépôt et à la diffusion de documents scientifiques de niveau recherche, publiés ou non, émanant des établissements d'enseignement et de recherche français ou étrangers, des laboratoires publics ou privés. 


\section{Crystallographic statistical study of decavanadate anion based-structures: toward a prediction of noncovalent interactions}

\begin{tabular}{|r|l|}
\hline Journal: & Crystal Growth \& Design \\
\hline Manuscript ID: & cg-2011-00236d.R1 \\
\hline Manuscript Type: & Article \\
\hline Author: & n/a \\
\hline Complete List of Authors: & $\begin{array}{l}\text { Bošnjaković-Pavlović, Nada; Ecole Centrale Paris, Laboratoire Structures, } \\
\text { Propriétés et Modélisation des Solides (SPMS), UMR CNRS 8580; } \\
\text { University of Belgrade, Faculty of Physical Chemistry } \\
\text { Prévost, Josselin; Ecole Centrale Paris, Laboratoire Structures, Propriétés } \\
\text { et Modélisation des Solides (SPMS), UMR CNRS 8580; University of } \\
\text { Belgrade, Faculty of Physical Chemistry } \\
\text { Spasojevic - de Biré, Anne; Ecole Centrale Paris, Laboratoire Structures, } \\
\text { Propriétés et Modélisation des Solides (SPMS), UMR CNRS 8580 }\end{array}$ \\
\hline & \multicolumn{2}{|l}{} \\
\hline
\end{tabular}




\title{
Crystallographic statistical study of decavanadate
}

\section{anion based-structures: toward a prediction of}

\section{noncovalent interactions}

\author{
Nada Bošnjaković-Pavlović ${ }^{1,2}$, Josselin Prévost $^{1,2}$ and Anne Spasojević-de Biré ${ }^{* 1}$ \\ ${ }^{1}$ Laboratoire Structures, Propriétés et Modélisation des Solides (SPMS), UMR CNRS \\ 8580, Ecole Centrale Paris, Grande Voie des Vignes, 92295 Châtenay-Malabry, France \\ ${ }^{2}$ Faculty of Physical Chemistry, University of Belgrade, P.O. Box 47, 11001 Belgrade, \\ Serbia
}

* to whom correspondence should be addressed: anne.spasojevic@ecp.fr 


\begin{abstract}
We have retrieved from the Cambridge Structural Database (CSD), the Inorganic Crystal Structure Database (ICSD) and the Protein Data Bank (PDB) decavanadate based compounds, in order to find intermolecular interactions between decavanadate oxygen atom and different proton donor type $(\mathrm{D}=\mathrm{O}, \mathrm{N}, \mathrm{C}) .63$ different structures have been found containing decavanadate anion, leading to 2975 intermolecular contacts belonging to the 48 structures for which the hydrogen bonds have been localised. In a previous study, (Bosnjakovic-Pavlovic et al., Inorg. Chem., 2009) we have predicted the preferential noncovalent interactions with the different oxygen atoms of the decavanadate anion. These predictions are confirmed, in the present study. Noncovalent interactions are strongly different as a function of the oxygen atom type. The Ob, triply-linked, and Oc, double-linked oxygen atoms, for which the electrostatic potential in the vicinity have the lowest value, are mainly involved in the strong as $\mathrm{O}-\mathrm{H} \cdots \mathrm{O}, \mathrm{N}-\mathrm{H} \cdots \mathrm{O}$ interactions, while the mono linked Of or Og are mainly involved in weakest noncovalent interactions such as $\mathrm{C}-\mathrm{H} \cdots \mathrm{O}$ or cation interactions. Binding properties of decavanadate anion in biological systems are illustrated using PDB. Anion binding behaviour in small-molecule structures and in macromolecular structures is in good agreement.

These results are important in the context of the various biological applications of the decavanadate such as, for example, inhibition of the $\mathrm{Ca}^{2+}$ ATPase, myosin ATPase, and new development in insulin mimetic.
\end{abstract}




\section{Graphical abstract}

We have performed a crystallographic statistical study of decavanadate anion basedstructures focalising on $\mathrm{O}-\mathrm{H} \cdots \mathrm{O}, \mathrm{N}-\mathrm{H} \cdots \mathrm{O}$ and $\mathrm{C}-\mathrm{H} \cdots \mathrm{O}$ noncovalent interactions from (Cambridge Structure Database) CSD, Inorganic Crystallographic Structure Databank (ICSD) and Protein Data Bank (PDB) bases. The noncovalent interactions are strongly different depending on the decavanadate oxygen atom type. The $\mathrm{Ob}$ and $\mathrm{Oc}$ oxygen atoms are mainly involved in the strong $\mathrm{O}-\mathrm{H} \cdots \mathrm{O}, \mathrm{N}-\mathrm{H} \cdots \mathrm{O}$ while $\mathrm{Of}$ or $\mathrm{Og}$ are mainly involved in weakest hydrogen bonds such as $\mathrm{C}-\mathrm{H} \cdots \mathrm{O}$ or cation interactions.

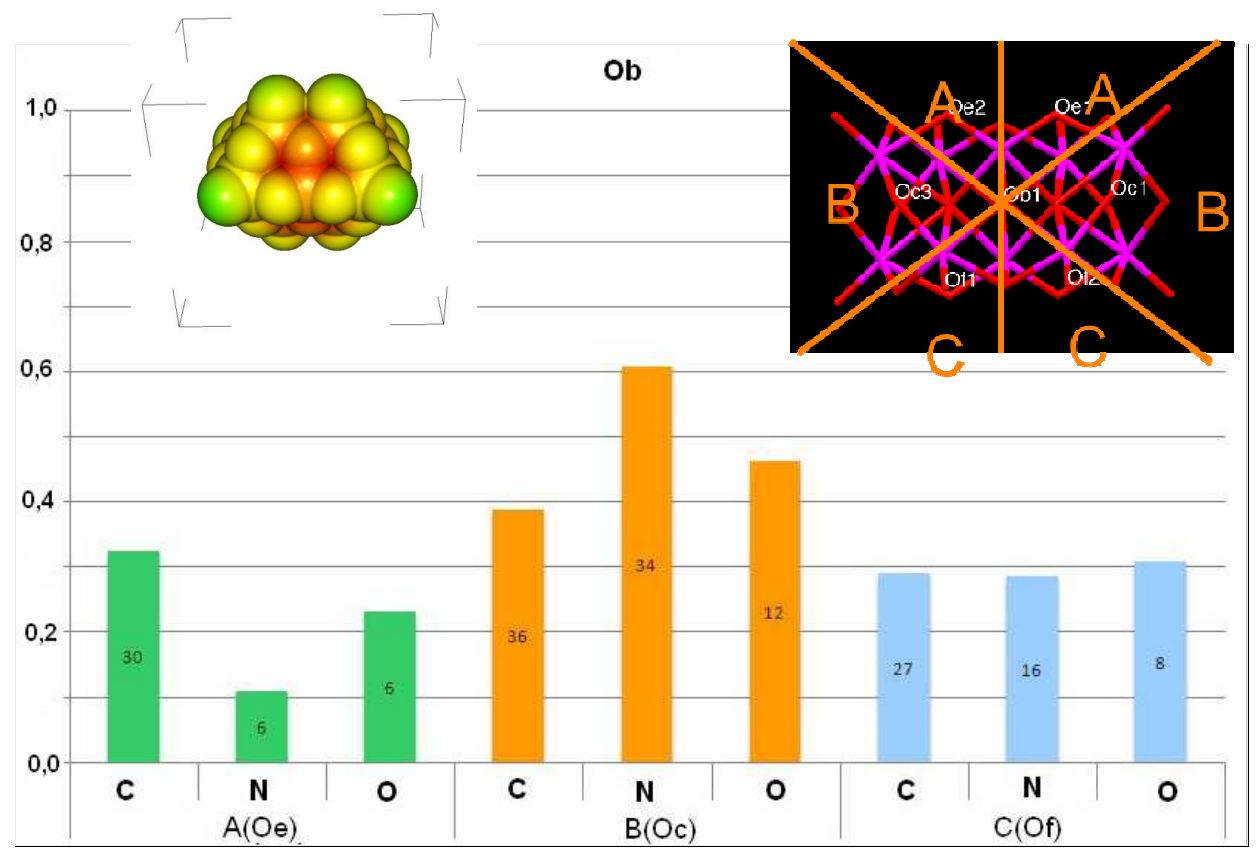




\section{Introduction}

Investigations of the interactions of the decavananadate $\left(\mathrm{V}_{10}\right)$ with peptides or proteins, which play fundamental role in biological systems, have been a subject of growing interest in recent years. It has been documented that these interactions are important since that the biological properties of $\mathrm{V}_{10}$ result from interactions with viral enzymes or viral cell envelopes. The understanding of these interactions at a molecular level is essential for the interpretation and the development of potent compounds with selective enzymatic affinity.

$\mathrm{V}_{10}$ as been referred of biochemical importance and is considered belonging to the major protein-bound species. ${ }^{1}$ For example, recent studies demonstrated that, after one and seven days of in vivo administration, $\mathrm{V}_{10}$, when compared to other oligomers, species, induces different effects on anti-oxidant enzymes, lipid peroxidation, subcellular vanadium distribution and tissue damage in liver, kidney and heart. ${ }^{2-3}$ However, its presence in significant amounts can be explained by the existence of special cell compartments where vanadium can be accumulated and preserved from decomposition acting as a protective "cage". Aureliano et al. have formulated the hypothesis that mitochondria might be a target for $\mathrm{V}_{10}{ }^{4}$ Recently, in vivo studies demonstrate that in mitochondria, where vanadium was shown to accumulate, ${ }^{2,5,6} \mathrm{nM}$ concentration of $V_{10}$ induces membrane depolarization, ${ }^{7}$ inhibition of oxygen consumption, ${ }^{8}$ necrotic cell death, ${ }^{9}$ inhibition of extracellular matrix (ECM) mineralization. ${ }^{10}$ Willsky et al. propose that $\mathrm{V}_{10}$ forms in the acidic compartment analogous to lysozyme in cells treated with 
vanadate, and ultimately is extruded into the medium. ${ }^{11}$ They confirm the possibility that $\mathrm{V}_{10}$ form intracellularly. It has also been reported that $\mathrm{V}_{10}$ inhibits or activates proteins. ${ }^{12-}$ 29 These studies have shown that $\mathrm{V}_{10}$ membranes targets are channels ${ }^{30-32}$ and metabotropic receptors ${ }^{33}$ but are also pumps such as $\mathrm{Ca}^{2+}$ ATP- ase. ${ }^{34}$

While the inhibition of enzymes by POV's has been well documented, the primary mechanism for biological activity remains elusive. Investigations of POM's in the presence of enzymes and proteins have provided additional information on their mode of action. The pionneer studies on the interaction between decavanadate and proteins were performed with ribonuclease, in $1973 .{ }^{35} \mathrm{Crans}^{36}$ and co-worker first have structurally characterized a decavanadate - dipeptide complex. Noncovalent interactions have been investigated through combined crystallographic, spectroscopic, and enzymatic studies with mutant as well as wild-type enzymes. ${ }^{37-41}$ Meicheng et al. observe hydrogen bonding interaction between the 4-ethylpyridinium cation and the decavanadate ion that involves doubly and triply oxygen atoms. ${ }^{40}$ Very weak hydrogen bonding interactions between guanidinium ion and singly and doubly coordinated oxygen atoms in decavanadate anions have also been observed. ${ }^{41}$ At a molecular level the mechanism of action is played via noncovalent interactions between the $\mathrm{V}_{10}$ anion and the biological target.

From a geometric point of view, the $\left[\mathrm{V}_{10} \mathrm{O}_{28}\right]^{6-}$ anion is represented in Figure 1. Due to the complexity of the structure, it is necessary to characterize precisely the different environment of oxygen and vanadium atoms. If we classified the oxygen atoms according to their vanadium coordination, four type of oxygen atoms are involved in this anion: $\mathrm{O} 1 \mathrm{x}$ - bonded to only one vanadium atom; $\mathrm{O} 2 \mathrm{x}$ - shared between two vanadium atoms; O3x - shared between three vanadium atoms. O6x - have a six-fold coordination 
of vanadium atom. Considering now different vanadium atoms, there are three types: type I, type II and type III, (Figure 1b). Thus, oxygen atoms have to be classified in subtypes according to new labels (type a, b, c, d, e, f, and g). In a previous study, ${ }^{42}$ we have experimentally determined the electron and electrostatic properties of $\mathrm{Na}_{3} \mathrm{~V}_{10} \mathrm{O}_{28}\left(\mathrm{C}_{4} \mathrm{~N}_{3} \mathrm{OH}_{5}\right)_{3}\left(\mathrm{C}_{4} \mathrm{~N}_{3} \mathrm{OH}_{6}\right) \quad 10 \mathrm{H}_{2} \mathrm{O}$ and we have analyzed carefully the hydrogen bonding network between $\mathrm{V}_{10}$ anion and other part in structure. Crystal structure of the title compound is stabilized by an extensive hydrogen bonding network, which involved the $\mathrm{V}_{10}$ anions, cytosine and water molecules. $\mathrm{V}_{10}$ anion is able to accept all type of proton donor (oxygen, nitrogen and carbon) letting the structure containing several varieties of intermolecular interactions, such as $\mathrm{O}-\mathrm{H} \cdots \mathrm{O}, \mathrm{N}-\mathrm{H} \cdots \mathrm{O}, \mathrm{C}-\mathrm{H} \cdots \mathrm{O}$. The main result of this study is that the noncovalent interactions are strongly different depending on the oxygen atom type. The $\mathrm{Ob}$ and $\mathrm{Oc}$ oxygen atoms, are involved mainly in the strong $\mathrm{O}-\mathrm{H} \cdots \mathrm{O}, \mathrm{N}-\mathrm{H} \cdots \mathrm{O}$, while Of or $\mathrm{Og}$ are mainly involved in weakest hydrogen bonds such as $\mathrm{C}-\mathrm{H} \cdots \mathrm{O}$ or cation interactions. We have determined the molecular electrostatic potential in order to visualize nucleophilic molecular regions and we have found that the most negative region of the electrostatic potential takes place in the vicinity of $\mathrm{Ob}$ and $\mathrm{Oc}$ atoms. Similar results have been previously found from ab initio theoretical calculations performed for an isolated $\left[\mathrm{V}_{10} \mathrm{O}_{28}\right]^{6-}$ anion. ${ }^{43-46}$ Therefore, the most basic accessible sites for protonation are oxygen atoms of type $b$ and $c$.

Analysis of interactions between $\mathrm{V}_{10}$ and organic part using the Cambridge Structural Data Base $(\mathrm{CSD})^{47}$ can provide structural evidence for the role of the anion. Hydrogen bonds and their environment have a well defined geometry in the crystalline state. CSD provides a large amount of experimental data that allows hydrogen bonds 
geometries to be analyzed at a high statistical level, ${ }^{48}$ and therefore CSD is a major source of knowledge on intermolecular interactions of all types. CSD have been used extensively in studies of common strong hydrogen bond having oxygen or nitrogen as donors and acceptors. ${ }^{49-54}$ Nowadays, the noncovalent interactions studies take two directions: i) the study of weak hydrogen bonding; major contribution of CSD analysis have been to support in identification of short $\mathrm{C}-\mathrm{H} \cdots \mathrm{O}$ contacts as hydrogen bonds ${ }^{55-56}$ or $\mathrm{C}-\mathrm{H} \cdots \pi$ interaction, ${ }^{57-58}$ ii) an increasing interest in the energy crystal landscape. ${ }^{59-62}$

Ferreira da Silva et al., ${ }^{63}$ published a survey concerning the donor-acceptor intermolecular interactions for the compounds containing the $\left[\mathrm{H}_{\mathrm{n}} \mathrm{V}_{10} \mathrm{O}_{28}\right]^{6-\mathrm{n}}$ anion, based on a CSD. They systematised the solid-state supramolecular motifs in order to understand the key factors determining the crystal packing of $\mathrm{V}_{10}$. They have concluded that crystal lattice packing in the solid state packing are closely related to the anion interaction with organic molecules, cations and / or water molecules. The three-dimensional supramolecular structure is formed by a network of $\mathrm{N}-\mathrm{H} \cdots \mathrm{O}, \mathrm{O}-\mathrm{H} \cdots \mathrm{O}$ and $\mathrm{C}-\mathrm{H} \cdots \mathrm{O}$ hydrogen bonds, in which the cations, anions and water molecules are involved. When the $\mathrm{V}_{10}$ are unprotonated and the cations are small, columbic interaction with inorganic cation and hydrogen bonds with organic cations and water molecules play an important role. Cations act as bridging atoms between the layers, forming the three-dimensional array.

According to our previous paper, we have ranked the oxygen atoms from the most negative to the less negative (Ob, Oe, Oc, Od, Of and $\mathrm{Og}$ ). The question, which arises, is the following: can we correlate this observation with the preferential noncovalent interactions which occurs in the different compounds for which the crystal structure is 
known? That means, is there any preferential interaction depending of the $\mathrm{V}_{10}$ different oxygen? Thus, the aim of this statistical study is to correlate the predictions with the observations in different $\mathrm{V}_{10}$ based structures and therefore to study if there are some trends in these interactions, according to the donor or the oxygen atom, or on the contrary, if there is no trend.

We have performed a statistical study on the $\mathrm{O}-\mathrm{H} \cdots \mathrm{O}, \mathrm{N}-\mathrm{H} \cdots \mathrm{O}$ and $\mathrm{C}-\mathrm{H} \cdots \mathrm{O}$ noncovalent interactions for structures which contain $\mathrm{V}_{10}$ anion, from (Cambridge Structure Database) $\mathrm{CSD}^{47}$, Inorganic Crystallographic Structure Databank (ICSD) ${ }^{64}$ and Protein Data Bank (PDB) ${ }^{65}$ bases and from crystallographic structures not included in these three crystallographic databases. ${ }^{42,66}$ We have investigated these interactions depending of the oxygen type of decavanadate: Ob, Oc, Od, Oe, Of and Og. We have founded 2975 contacts: $866 \mathrm{O}-\mathrm{H} \cdots \mathrm{O}$ interactions, $889 \mathrm{~N}-\mathrm{H} \cdots \mathrm{O}$ and $1220 \mathrm{C}-\mathrm{H} \cdots \mathrm{O}$ interactions. This paper presents an analysis of the interactions according to the following parts: i) general analysis of the geometry of hydrogen bond; ii) a study of the influence of different binding type according to the different oxygen atoms type, proton type, ..., iii) and finally, a comparative analysis with macromolecular structures. Binding properties of $\mathrm{V}_{10}$ anion in biological system are illustrated using PDB.

\section{Methods}

\subsection{CSD}

The $\mathrm{CSD}^{47}$ was searched for compound containing $\mathrm{V}_{10}$ anion and retrieved depending on the oxygen type $\mathrm{Ob}, \mathrm{Oc}$, Od, Oe Of and Og (30 structures found). ${ }^{67}$ Con 
Quest $^{68}$ software was used to search intermolecular contacts. The searches were restricted to entries with: a) error-free coordinate sets in CSD check procedures; b) no crystallographic disorder; c) no polymeric connections, d) crystallographic R factor lower than 0.10 and e) protons were placed at their normalized position. For each interaction, we have determined the $\mathrm{D}-\mathrm{H} \cdots \mathrm{O}$ distance and angle. The search reveals interactions which are shorter than the sum of the van der Walls radii. The 33 structures found are listed in Table 1. In bold those (30) were the proton was localized.

\subsection{ICSD}

The $\operatorname{ICSD}^{64}$ was searched for compound containing $\mathrm{V}_{10}$ anion. The Mercury software has been used to determine the geometry of the 14 structures found for which the proton was localized. ${ }^{66,69 a-k}$

\subsection{PDB}

To compare the small molecule results with those from macromolecular structures, the $\mathrm{PDB}^{65}$ was searched for $\mathrm{V}_{10} \cdots \mathrm{H}$-donor interactions. The enzymedecavanadate complexes were found through a PDB search using the 'decavanadate' keyword. 3 structures were found. We have investigated the intermolecular interactions between the decavanadate anion and the protein structure. Molekel software ${ }^{70}$ has been used to visualize some results.

\section{Results and discussion}

\subsection{Geometrical description}


From the electrostatic potential (EP) values, we have predicted the preferential non-covalent interactions (Figure 2) with the different oxygen atoms of the $\mathrm{V}_{10}$ anion. ${ }^{42}$ The strongest interactions take place in the most negative electrostatic potential region (the red part), and the weakest interactions in the less negative region (the blue part). This scheme does not mean that there is no interaction of $\mathrm{N}-\mathrm{H} \cdots \mathrm{O}$ type at the Of or Og site, it means, that the strongest interactions take place preferentially at the $\mathrm{Ob}$ and $\mathrm{Oc}$ site and the weakest at the Of and Og site.

Figure 3 represents the D...O distance and the D-H..O angle distribution where $\mathrm{D} \cdots \mathrm{O}$ distance is less than $3.5 \AA$ ( $\mathrm{D}$ is the donor atom). $866 \mathrm{O}-\mathrm{H} \cdots \mathrm{O}$ interactions has been analyzed. The $\mathrm{O} \cdots \mathrm{H}$ distances show an accumulation between 1.7 and $2.2 \AA$ (Figure $3 \mathrm{a}$ ) and another lower peak at about $2.6 \AA$, while the $\mathrm{D}-\mathrm{H} \cdots \mathrm{O}$ angle exhibits values between 150 and $180^{\circ}$ (Figure $3 \mathrm{~b}$ ). Preference for linearity in the $\mathrm{O}-\mathrm{H} \cdots \mathrm{O}$ case has been assessed by analyzing the distribution of angle. ${ }^{48}$ The percentage of short $\mathrm{O} \cdots \mathrm{O}$ interactions (about $48 \%$ ) found for the first peak (at lower distance) could be taken as an indicator of the strength of this interaction type. Statistically, one can observe two peaks of $\mathrm{O} \cdots \mathrm{O}$ interactions a strong one and a weaker one. $889 \mathrm{~N}-\mathrm{H} \cdots \mathrm{O}$ interactions show wide variation in $\mathrm{N} \cdots \mathrm{O}$ distances as well as significant variation in the angle (Figure $3 \mathrm{c}$ and $3 \mathrm{~d}$ ). The geometry of $\mathrm{C}-\mathrm{H} \cdots \mathrm{O}$ interactions is analyzed using 1220 interactions from 32 crystal structures. All these interactions follow the trend expected for hydrogen bonds, namely for $\mathrm{C}-\mathrm{H} \cdots \mathrm{O}$ angle opens up as the distance between donor and acceptor increases. C$\mathrm{H} \cdots \mathrm{O}$ interactions are mainly at long distance (2.4 to $3.0 \AA)$ and angle from 110 to $160^{\circ}$. In term of angularity, all these interactions follow the trend expected for hydrogen bonds. $^{56}$ 
In order to go deeply in a geometrical parameter description, the relationship between $\mathrm{D} \cdots \mathrm{O}$ and $\mathrm{D}-\mathrm{H} \cdots \mathrm{O}$ is drawn in Figure 4 according to the $\mathrm{V}_{10}$ different oxygen types which are represented in different color (from red to blue). These colors correspond to the color used for visualization of electrostatic potential values at the $\mathrm{V}_{10}$ molecular surface (Figure 2). O-H...O noncovalent interactions (Figure 4a) for the oxygen Ob, Oc and Od are mainly at a short length (1.7 to $2.1 \AA)$ and high angles (140 to $\left.180^{\circ}\right)$ whereas for Of and Og, interactions are at longer distances (2.3 to $3.0 \AA$ ) and smaller angles (90 to $100^{\circ}$ ). The same observations can be made for the $\mathrm{N}-\mathrm{H} \cdots \mathrm{O}$ interactions (Figure $4 \mathrm{~b}$ ) in a less pronounced way. Concerning the $\mathrm{C}-\mathrm{H} \cdots \mathrm{O}$ interactions there is no particular trend according to the type of the oxygen of $\mathrm{V}_{10}$ but the interactions are mainly at long distance (2.3 to $3.0 \AA$ ) and angle from 100 to $160^{\circ}$ (Figure 4c). It is therefore clear, that the directionality of the noncovalent interaction depends on the oxygen atom type. Ob and Oc oxygen atoms induce strong directionality for $\mathrm{O}-\mathrm{H} \cdots \mathrm{O}$ and $\mathrm{N}-\mathrm{H} \cdots \mathrm{O}$ interactions with short distances and high angle. Of and $\mathrm{Og}$ can form $\mathrm{O}-\mathrm{H} \cdots \mathrm{O}$ and $\mathrm{N}-\mathrm{H} \cdots \mathrm{O}$ interactions but with very long distances $(2.3-2.7 \AA)$ and with smaller angle $\left(100\right.$ to $\left.140^{\circ}\right)$. This explains the two peaks observed in Figure 3 for $\mathrm{O} \cdots \mathrm{O}$ and a wider dispersion for $\mathrm{N} \cdots \mathrm{O}$ interaction.

\section{2. $\mathrm{V}_{10}$ binding}

Figures 3 and 4 have revealed geometrical characteristics in noncovalent interactions according to the donor or the $\mathrm{V}_{10}$ oxygen atom type. The next step consists on focalising on the binding of each $\mathrm{V}_{10}$ oxygen atom type. In Figure 5, 2061 interactions with $\mathrm{O}-\mathrm{H} \cdots \mathrm{O}$ or $\mathrm{N}-\mathrm{H} \cdots \mathrm{O}<145^{\circ}$ have been rejected in order to conserve those which are significant. This cut-off value has been chosen according to the existence of hydrogen 
bonds Bond Critical Point in charge density studies of $\mathrm{V}_{10}$ structures. $^{42}$ Figure $5 \mathrm{a}$ represents the ratio of each type of $\mathrm{O}-\mathrm{H} \cdots \mathrm{O}, \mathrm{N}-\mathrm{H} \cdots \mathrm{O}$ and $\mathrm{C}-\mathrm{H} \cdots \mathrm{O}$ interactions, after normalization by the number of each type of interactions, for a corresponding $\mathrm{O}_{\mathrm{dv}}$ oxygen. For example, for $\mathrm{Ob}$ and $\mathrm{Oc}, \mathrm{O}-\mathrm{H} \cdots \mathrm{O}_{\mathrm{dv}}$ and $\mathrm{N}-\mathrm{H} \cdots \mathrm{O}_{\mathrm{dv}}$ interactions represents about $80 \%$ of the interactions whereas for Oe and $\mathrm{Og}$, they represent only about $50 \%$. It is in agreement with the fact that $\mathrm{Ob}$ and $\mathrm{Oc}$ induce hydrogen bonds with strong directionality, which is not the case for Of and Og. In order to describe more precisely the interactions, we have to take into account that the different $\mathrm{V}_{10}$ oxygen atom types have not the same occurrence in the anion structure. For example, a noncovalent interaction has two times more probability to take place with an $\mathrm{Oc}$ atom than an $\mathrm{Ob}$ (Figure 1). Within this normalization, Figure $5 \mathrm{~b}$ indicates that $\mathrm{C}-\mathrm{H} \cdots \mathrm{O}_{\mathrm{dv}}$ interactions are more frequent for each type (from $40 \%$ to $75 \%$ ) and $\mathrm{N}-\mathrm{H} \cdots \mathrm{O}_{\mathrm{dv}}$ interactions are less frequent (28 to $5 \%$ ). Ob or Oc are more polyvalent than Of or Od. Finally, one has to take into account the nature of the donor molecules. Therefore, we have counted for each structure, the possibility of each molecule to take part in a $\mathrm{D}-\mathrm{H} \cdots \mathrm{O}_{\mathrm{dv}}$ interaction, and normalized by using this value (Figure 5c). This graph is nearly the same as the one with only normalization by the occurrence of each $\mathrm{O}_{\mathrm{dv}}$, but predominance of $\mathrm{C}-\mathrm{H} \cdots \mathrm{O}_{\mathrm{dv}}$ interactions is less high. It shows that for a same number of possible non covalent bond for a given structure, carbon atom makes more noncovalent interactions than oxygen or nitrogen atom. Oxygen and nitrogen atoms are similar, but nitrogen makes a little more noncovalent interactions than oxygen atom for a same number of bonds. This graph also indicates that $\mathrm{Ob}$ and $\mathrm{Oc}$ are polyvalent (each type of interactions are represented in similar proportions), but $\mathrm{Oe}$ and $\mathrm{Og}$ have more contacts from $\mathrm{C}-\mathrm{H} \cdots \mathrm{O}$ type $(65-70 \%)$ 
while Od and Of have about $55 \%$ of $\mathrm{C}-\mathrm{H} \cdots \mathrm{O}$ interactions. Once again it is in agreement with the type of interaction made by carbon (not strong) and by oxygen and nitrogen (stronger), while the Of behaviour seems to be an exception.

\subsection{Multifurcated hydrogen bonds and mutiacceptor oxygen}

Another interesting point of the description of the noncovalent interactions with a $\mathrm{V}_{10}$ anion is the number of interactions per hydrogen (multifurcation). Contacts with an angle $\mathrm{O}-\mathrm{H} \cdots \mathrm{O}$ or $\mathrm{N}-\mathrm{H} \cdots \mathrm{O}<145^{\circ}$ have been rejected. About $60 \%$ of the interactions arised from monofurcated protons, while $25 \%$ from bifurcated protons (one proton for two interactions) and $15 \%$ from trifurcated protons (one proton for three interactions) (Figure S1 in supplementary material). On the other side, we have studied the number of interaction according to a given oxygen $\mathrm{V}_{10}$ atom type. Contacts after rejection and normalization by the number of contacts for a considered oxygen atom (48 structures analysed) are represented in red color (Figure 6) by the occurrence of the oxygen atom type in $\mathrm{V}_{10}$ anion. That means that in average $\mathrm{Ob}$ presents a little more than one contact while Og has a an average of more than 1,5 contacts per oxygen atom. In the green bar the oxygen atoms which have no contact, have been excluded of the statistic. In blue bar, only contacts from monofurcated protons are considered. This figure shows that considering all contacts, each oxygen atom type has at least one contact in average. The fact that $\mathrm{Ob}$ has mainly one noncovalent interaction, could be explained by its position in the $\mathrm{V}_{10}$ anion, (a triply bonded with vanadium) which is i) less accessible than the other types and ii) generally strongly bonded (a closer geometry). The oxygen types which have the most contacts are Od, Of and Og. Og presents hydrogen bonds more than two in 
average. The number of contacts from monofurcated protons is quite smaller letting all types having less than one contact from monofurcated proton.

\subsection{Deeply insight into the localisation of the proton near the $V_{10}$ anion. Influence of the $2^{\text {nd }}$ neighbours}

To go deeply insight into the noncovalent interactions with the $\mathrm{V}_{10}$ anion, we have also studied the proton position in the neighbourhood of the corresponding $\mathrm{O}_{\mathrm{dv}}$, by analyzing its proximity to $\mathrm{O}_{\mathrm{dv}}$ in term of verticality and in term of influence with the neighboured oxygen atoms. To characterize the proximity of the $\mathrm{O}_{\mathrm{dv}}$ verticality, we have used a $\gamma$ angle (Figure $1 \mathrm{~b}$ ). The angle $\gamma$ indicates the position of the proton compared with the verticality of the corresponding oxygen atom. Analysis of $\gamma$ angle (Figure 7, and Figures S3, S4, S5 in supplementary material) shows a difference depending on the oxygen atom and donor type. For $\mathrm{O}-\mathrm{H} \cdots \mathrm{O}_{\mathrm{dv}}$ and $\mathrm{N}-\mathrm{H} \cdots \mathrm{O}_{\mathrm{dv}}$ interactions, $\mathrm{Ob}$ and $\mathrm{Oc}$ which are involved in strong hydrogen bonds, the $\gamma$ angle is high $\left(120\right.$ to $\left.180^{\circ}\right)$. Dispersion can be observed for Of, but $\mathrm{Og}$ has a $\gamma$ angle smaller than $\mathrm{Ob}$ and $\mathrm{Oc}$ ranging mainly from 70 to $140^{\circ}$. For the $\mathrm{C}-\mathrm{H} \cdots \mathrm{O}_{\mathrm{dv}}$ interactions the behaviour is not so clear. Under $120^{\circ}$, mainly interactions with Of and Og are presents but over it's more homogeneous. Therefore, $\gamma$ seems, to a certain extent, to have a similar behaviour as the $\mathrm{D}-\mathrm{H} \cdots \mathrm{O}_{\mathrm{dv}}$ angle. The observation of the dihedral angle $\mathrm{X}-\mathrm{O}_{\mathrm{dv}} \cdots \mathrm{H}-\mathrm{D}$ versus the $\mathrm{O}_{\mathrm{dv}} \cdots \mathrm{H}$ distance, where $\mathrm{X}$ is $\mathrm{V}$ when $\mathrm{O}_{\mathrm{dv}}$ is $\mathrm{Of}$ or $\mathrm{Og}$ and a dummy atom leading to $\mathrm{X}-\mathrm{O}_{\mathrm{dv}}$ perpendicular to the plane of the neighbours of $\mathrm{O}_{\mathrm{dv}}$ give no particular behaviour.

In order to check the influence of the neighbours, we have then analysed the proton position in the neighbourhood of the corresponding $\mathrm{O}_{\mathrm{dv}}$ (Figure 8). For each noncovalent interaction, the distances between the proton and the first neighbours of the corresponding $\mathrm{O}_{\mathrm{dv}}$ have been determined. We have divided the neighbourhood of the $\mathrm{O}_{\mathrm{dv}}$ in sectors containing one of the neighbours in order to determine in which sector the 
proton lies. Results are presented separately for the oxygen atom type and for each type frequency is given in each sector according to the donor. The number of identical sectors is taken into account. Interactions with angles $\mathrm{N}-\mathrm{H}-\mathrm{O}_{\mathrm{dv}}$ and $\mathrm{C}-\mathrm{H}-\mathrm{O}_{\mathrm{dv}}<145^{\circ}$ have been rejected. There is generally no particular behaviour for $\mathrm{C}-\mathrm{H} \cdots \mathrm{O}_{\mathrm{dv}}$ interactions but some differences for $\mathrm{N}-\mathrm{H} \cdots \mathrm{O}_{\mathrm{dv}}$ and $\mathrm{O}-\mathrm{H} \cdots \mathrm{O}_{\mathrm{dv}}$ interactions. For $\mathrm{Ob}$, the frequency of protons which are in the sector $\mathrm{B}$ is a little higher for $\mathrm{N}-\mathrm{H} \cdots \mathrm{O}_{\mathrm{dv}}$ and $\mathrm{O}-\mathrm{H} \cdots \mathrm{O}_{\mathrm{dv}}$ interactions. The neighbours are Oc, Oe and Of which are on a side of $\mathrm{V}_{10}$ have more or less a similar position in the space. As Oc is a more electronegative atom than Oe and Of, therefore more attractive, it may explain the higher proportion in the sector B.

For Oc (Figure S6a), we have taken into account the fact that Of and Og are not in the same plane as the other neighbours. After that, the graph shows that Of and Og have only a few protons above them, which can be explained by the fact that they are not in the plane of the other neighbours but are above the plan and therefore unable the proton position. Most of the protons of $\mathrm{O}-\mathrm{H} \cdots \mathrm{O}_{\mathrm{dv}}$ interactions are in sector $\mathrm{F}$ (above Oe), which has the most free environment. For $\mathrm{N}-\mathrm{H} \cdots \mathrm{O}_{\mathrm{dv}}$ interactions, a little more are in sector D (above Od which is more electronegative) but the differences are not very significative between sectors. Od (Figure S6b) and Og (Figure 8b) are not in the same plane than Oc. For the same reasons, as those expressed for Oc almost no proton is in the sector B. They are above Oc.

For Oe (Figure S6c), there are two sectors A and B with Oc and Ob respectively. The graph shows that $\mathrm{O}-\mathrm{H} \cdots \mathrm{O}_{\mathrm{dv}}$ and $\mathrm{N}-\mathrm{H} \cdots \mathrm{O}_{\mathrm{dv}}$ interactions are mainly in the sector $\mathrm{A}$, which may be explained by the fact that Oc has a freer environment although $\mathrm{Ob}$ is more electronegative. For Of, there are no significant differences between the two sectors A and $\mathrm{B}$ (Oc and $\mathrm{Ob}$ respectively). Only a little more are above $\mathrm{Ob}$, which is the contrary as the case of Oe, but which might be explained by the fact that a lot of protons are bifurcated between the two Of, therefore above Ob. For Og (Figure 8b), there are three different sectors A, B and C, above Oe, Oc and Od respectively. Mainly, $\mathrm{N}-\mathrm{H} \cdots \mathrm{O}_{\mathrm{dv}}$ 
interactions are in the sector $\mathrm{B}$, whereas $\mathrm{O}-\mathrm{H} \cdots \mathrm{O}_{\mathrm{dv}}$ interactions are more in the sectors $\mathrm{A}$ and $\mathrm{C}$ with the same quantity.

The observation of the proton in the neighbourhood of the corresponding $\mathrm{O}_{\mathrm{dv}}$ indicates that there is a competition between the steric effect and the EP values. The steric effect seems to be predominant and protons of $\mathrm{O}-\mathrm{H} \cdots \mathrm{O}_{\mathrm{dv}}$ and $\mathrm{N}-\mathrm{H} \cdots \mathrm{O}_{\mathrm{dv}}$ interactions are more above $\mathrm{O}_{\mathrm{dv}}$ with the free environment. Steric effect is particularly important for neighbour atoms which are not in the same plane as the others. In case where there is no steric effect, EP values are important and protons are above the more electronegative $\mathrm{O}_{\mathrm{dv}}$.

\subsection{Decavanadate binding with proteins}

While the inhibition of enzymes by $\mathrm{V}_{10}$ 's has been well documented, the primary mechanism for biological activity remains elusive. Previously reported studies ${ }^{37,41}$ illustrate the importance of the noncovalent interactions between $\mathrm{V}_{10}$ and peptides. It is clear from these studies that the vanadate interacts very strongly with positively charged proteins. Therefore, this is particularly important if we take into account the possible interaction mechanism of $\mathrm{V}_{10}$ with proteins, where formation and breaking of hydrogen bonds presumably play fundamental role. From the chemical point of view, types of interactions realized in small molecule are identically to those observed in protein. As in the case in small structure, the $\mathrm{V}_{10}$ can be bonded by varies modes of interactions.

Three structures have been retrieved from $\mathrm{PDB},{ }^{65}$ Acid phosphatase A (2d1g), ${ }^{71}$ Tyrosine kinase (PDB ID 3gqi) ${ }^{72}$ and $\mathrm{Ca}^{2+}$ ATPase (PDB ID 1kju) coordinates are only available for the two first structures (Figure 9). Acid phosphatase A is a respiratory burstinhibiting acid phosphatase from the American Centers for Disease Control and Prevention (Category A bioterrorism agent) Francisella tularensis and prototype of a 
super-family of acid phosphatases and phospholipases C. Felts ${ }^{71}$ has reported the $1.75-\AA$ resolution crystal structure of Acid phosphatase A complexed with the inhibitor orthovanadate, the first published structure for any member of this super-family. Nevertheless, the precision of this structure could be taken as $0.01 \AA$ on the interatomic distances, and $3^{\circ}$ on the angles. Therefore that allows us to study precisely the intermolecular network. A tyrosine kinase is an enzyme that can transfer a phosphate group from ATP to a protein in a cell. The phosphates inhibitor sodium orthovanadate was applied in order to prevent dephosphorilation of tyrosine kinase. Crystal complex of tyrosine kinase - protein were not formed in the absence of $2 \mathrm{mM}$ vanadate. Table 2 summarizes the intermolecular interactions between $\mathrm{V}_{10}$ and the rest of the structure, in these two protein structures. In $\mathbf{2 d 1 g}, \mathrm{V}_{10}$ anion is linked to the $\mathrm{B}$ chain of the asymmetric unit through three histidine and a lysine, linked to the A chain (obtained with a symmetry operation) through two asparagine, and linked to one water molecule. In 3gqi structure, $\mathrm{V}_{10}$ is binded with the asparagine (Asn), arginine molecules and aspartic acid. The contact $\mathrm{Ob} \cdots \mathrm{N}_{\text {Asn }}$ with the distance $\mathrm{N} \cdots \mathrm{O}$ about $2.62 \AA$ is the shortest contact, and can be assumed as hydrogen bond.

In both structures, the stronger interactions take place on the most reactive oxygen atoms $(\mathrm{N}-\mathrm{H} \cdots \mathrm{O}$ interactions with a $\mathrm{dN} \cdots \mathrm{O}<2.70 \AA$ at $\mathrm{Ob}, \mathrm{Oc})$. This is in agreement with the experimental results from Crans et al., where they have found that the protonated amino terminus of the Gly-Gly dipeptide are connected with triply bridging oxygen atom of decavanadate anion $(\mathrm{Ob})$ via hydrogen bonds. $\left(\mathrm{d}_{\mathrm{N}-\mathrm{H} \cdots \mathrm{O}}=2.707(4) \AA\right)$. Therefore, these results show that the $\mathrm{V}_{10}$ noncovalent behavior we have observed, remains the same when the anion is bounded to a protein. 


\subsection{Cation interaction}

Another interesting result can be deduced from statistical study on a selection of inorganic and organic structures. The structures analyzed ${ }^{69 a, d, f, g, i, k ; 73 a-j}$ contain mainly $\mathrm{Na}^{+}, \mathrm{K}^{+}$, or $\mathrm{Ca}^{2+}$ cations due to the fact that these cations are generally involved in the enzymes activated or inhibited by $\mathrm{V}_{10}$. In table 1 , the noncovalent interactions are classified by the oxygen type of the $\mathrm{V}_{10}$. Concerning the cation interactions, one can observe that the cation are mainly linked to the Of oxygen than to the Og atom, while these two atoms present equivalent values of electrostatic potential. Therefore, cation with the highest positive charge forms a coordination polyhedron with the molecule of water. The less positive cation includes $\mathrm{V}_{10}$ anion in its coordination polyhedron. This is generally done with Of.

\section{Conclusion}

Study of polyoxovanadate containing organic molecules, especially the role of the organic cations placed in the structure of the decavanadate is a key-factor in the understanding of the direct interactions of vanadate with cellular proteins and enzymes. This could be an important key to reveal the physiological functions of vanadium oxoanions.

This work represents a systematic description and interpretation of noncovalent interaction including $\mathrm{V}_{10}$. The noncovalent interactions are strongly different depending on the oxygen atom type. The $\mathrm{Ob}$ and $\mathrm{Oc}$ oxygen atoms are involved mainly in the strong $\mathrm{O}-\mathrm{H} \cdots \mathrm{O}, \mathrm{N}-\mathrm{H} \cdots \mathrm{O}$ while Of or $\mathrm{Og}$ are mainly involved in weakest hydrogen bonds such as 
$\mathrm{C}-\mathrm{H} \cdots \mathrm{O}$ or cation interactions. These statistical observations are completely in agreement with our experimental determination of the electrostatic potential and its transferability property we have previously established. ${ }^{42}$ Due to the potent different types of interaction (strong and weak DH...O bonds, cations...O), $\mathrm{V}_{10}$ could definitively try to be used, as a crystallization agent. That could be done in the case where orthovanadate is an inhibitor. The $\mathrm{pH}$ conditions have to be carefully controlled. Our H-bond or cation interaction predictions fit well with two protein structures (2d1g and 3gqi). It could even help for determining some remaining water molecules in further structures. Our atomic net charges, ${ }^{42}$ and our H-bond and cation interaction predictions could be suitably used in the docking computations ${ }^{18,19,30}$ and would probably give better results than the common used charges.

\section{Acknowledgements}

A part of this paper, have been done during the join PhD thesis of NB-P between the University of Belgrade, Faculty of Physical Chemistry and Ecole Centrale Paris. The authors would thank the French foreign Minister for a COCOOP support on this project. NB-P would thank the Ministry of Science and Technological Development of the Republic of Serbia (Project 142043) and Ecole Centrale Paris for assistant professor invited position. The second part of this paper was the subject of the Master-1 internship exchange at the University of Belgrade, Faculty of Physical Chemistry of JP, JP thanks the Faculty of Physical Chemistry for its welcome.

\section{Supporting Information Available.}


Figures S-1 to S-6 present additional representation of the noncovalent interactions. This material is available free of charge via the Internet at http://pubs.acs.org.

1

2

3

4

5

6

7

8

9

10

11

12

13

14

15

16

17

18

19

20

21

22

23

24

25

26

27

28

29

30

31

32

33

34

35

36

37

38

39

40

41

42

43

44

45

46

47

48

49

50

51

52

53

54

55

56

57

58

59

60 


\section{References}

(1) Aureliano, M.; Crans, D. J. Inorg. Biochem. 2009, 103, 536-546, b) Aureliano, M. Dalton Trans 2009, 9093-9100.

(2) Soares, S. S.; Aureliano, M.; Joaquim, N.; Coucelo, J.M. J. Inorg. Biochem. 2003, 94, $285-290$.

(3) Aureliano, M.; Joaquim, N.; Sousa, A.; Martins, H.; Coucelo, J. M. J. Inorg. Biochem. 2002, 90, 159-165.

(4) Aureliano, M.; Gandara, R. M. C. J. Inorg. Biochem. 2005, 99, 979-985.

(5) Soares, S. S.; Martins, H.; Coucelo, J.; Duarte, R. O.; Gutiérrez-Merino, C.; Moura, J. J. G.; Aureliano, M. J. Inorg. Biochem. 2007, 101, 80-88.

(6) Soares, S. S.; Martins, H.; Aureliano, M. Arch. Environ. Contam. Toxicol. 2006, 50, 60-64.

(7) Soares, S. S.; Gutiérrez-Merino, C.; Aureliano, M. J. Inorg. Biochem. 2007, 101, 789-796.

(8) Soares, S. S.; Gutiérrez-Merino, C.; Aureliano, M. Aquat. Toxicol. 2007, 83, 1-9.

(9) Soares, S. S.; Henao, F.; Aureliano, M.; Gutiérrez-Merino, C. Chem. Res. Toxicol. 2008, 21, 607-618.

(10) Tiago, D. M.; Laizé, V.; Cancela, M. L.; Aureliano, M. Cell Biol. Toxicol. 2008, 24, 253-263.

(11) a)Willsky, G.R., Chasteen, N.D. Editor, Vanadium in Biological Systems: Physiology and Biochemistry, Kluwar Academic Publishers, London 1990, 1-24. b) Willsky, G.R., White, D.A., McCabe, B.C. J. Biol. Chem. 1984, 259, 13273-13281. 
(12) DeMaster, E. G.; Mitchell, R. A. Biochemistry 1973, 12, 3616-3621.

(13) Dux, L.; Martonosi, A. J. Biol. Chem. 1983, 258, 2599-2603.

(14) Maurer, A.; Fleischer, S. J. Bioenerg. Biomembr. 1984, 16, 491-505.

(15) Csermely, P.; Martonosi, A.; Levy, G. C.; Ejchart, A. J. Biochem. J. 1985, 230, 807815.

(16) Hua, S.; Inesi, G.; Toyoshima, C. J. Biol. Chem. 2000, 275, 30546-30550.

(17) Messmore, J. M.; Raines, R. T. Archive Biochem. Biophys. 2000, 381, 25-30.

(18) Pezza, R. J.; Villarreal, M. A.; Montich, G. G.; Argarana, C. E. Nucleic Acids Res. 2002, 30, 4700-4708.

(19) Tiago, T.; Martel, P.; Gutiérrez-Merino, C.; Aureliano, M. Bioch. Bioph. Acta Proteins Proteonics 2007, 1774, 474-480.

(20) Pluskey, S.; Mahroof-Tahir, M.; Crans, D. C.; Lawrence, D. S. Biochem. J. 1997, $321,333-339$.

(21) Ramos, S.; Manuel, M.; Tiago, T.; Gandara, R. M. C.; Duarte, R.; Moura, J. J. G.; Gutiérrez-Merino, C.; Aureliano, M. J. Inorg. Biochem. 2006, 100, 1734-1743.

(22) Yraola, F.; Garcia-Vicente, S.; Marti, L.; Albericio, F.; Zorzano, A.; Royo, M. Chem. Biol. Drug Des. 2007, 69, 423-428.

(23) Choate, G.; Mansour, T. E. J. Biol. Chem. 1979, 254, 11457-11462.

(24) Ramasarma, T.; Mackellar, W.; Crane, F. L. Indian J. Biochem. Biophys. 1980, 17, $163-167$.

(25) Ramasarma, T.; Mackellar, W.; Crane, F. L. Biochim. Biophys. Acta 1981, 646, 8898. 
(26) Rao, A. V. S.; Ramasarma, T. Biochim. Biophys. Acta-Gene. Subj. 2000, 1474, 321-330.

(27) Pereira, M. J.; Carvalho, E.; Eriksson, J. W.; Crans, D. C.; Aureliano, M. J. Inorg. Biochem. 2009, 103, 1687-1692.

(28) Jiang, M.; Han, Y. T.; Li, Y. T.; Wu, Z. Y.; Yan, C. W. Polish Journal of Chemistry 2009, 83, 1849-1858.

(29) Ramos, S.; Duarte, R. O.; Moura, J. J. G.; Aureliano, M. Dalton Transactions 2009, $38,7985-7994$.

(30) Nilius, B.; Prenen, J.; Janssens, A.; Voets, T.; Droogmans, G. J. Physiol. London 2004, 560, 753-765.

(31) Proks, P.; Ashfield, R.; Ashcroft, F. M. J. Biol. Chem. 1999, 274, 25393-25397.

(32) Csanady, L.; Adam-Vizi, V. J. Gen. Physiol. 2004, 123, 743-757.

(33) Michel, A. D.; Xing, M.; Thompson, K. M.; Jones, C. A.; Humphrey, P. P. A. Eur. J. Pharmacol. 2006, 534, 19-29.

(34) Hua, S.; Inesi, G.; Toyoshima, C. J. Biol. Chem. 2000, 275, 30546-30550.

(35) De Master, E.G., Mitchell, R.A. Biochemistry 1973, 12, 2616-3621.

(36) Crans, D. C.; Mahroof-Tahir, M.; Anderson, O. P.; Miller, M. M. Inorg. Chem. 1994, 33, 5586-5590

(37) Pai, E.F.; Sachsenheimer, W.; Schirmer, R.H.; Schulz, G.E.; J. Mol. Biol. 1977, 114, $37-45$.

(38) Crans, D.C. Comment Inorg. Chem. 1994, 16, 1-33.

(39) Crans, D.C. Comment Inorg. Chem. 1994, 16, 35-76.

(40) Meicheng, S.; Lifeng, W.; Youqi, T. T. Sci. Sin, (Ser B) XXVII 2 (1984) 137-148. 
(41) Wang, X.; Liu, H.-X.; You, X.X.; You, X.-Z. Polyhedron 1993, 12, 77-81.

(42) Bošnjaković-Pavlović, N.; Spasojević-de Biré, A.; Tomaz, I.; Bouhmaida, N.; Avecilla, F.; Mioč, U.; Costa Pessoa, J.; Ghermani, N.E. Inorg. Chem. 2009, 48, 97429753.

(43) Rohmer, M.M.; Ernenwein, R.; Ulmschneider, M.; Wiest, R.. Benard, M. Int. J. Quantum Chem. 1991, 40, 723-743.

(44) Kempf, J.Y.; Rohmer, M.M.; Poblet, J.M.; Bo, C.; Benard, M. J. Am. Chem. Soc. 1992, 114, 1136-1146.

(45) Rohmer, M.M.; Benard, M.; Blaudeau, J.P.; Maestre, J.M.; Poblet, J.M. Coord. Chem. Rev. 1998, 178-180, 1019-1049.

(46) Henry, M. J. Cluster Science 2002, 13, 437-458.

(47) Allen, F.H. Acta Cryst. 2002, B58, 380-388.

(48) Steiner, T. Angew. Chem. Int. Ed. 2002, 41, 48-76.

(49) Steiner, T.; Saenger, W. Acta Crystallog. 1992, B48, 819-827.

(50) Rychlewska, U. Eng. Cryst. Mater. Prop. State Art Model. Design App. 2008, 407427.

(51) Braga, D.; Grepioni, F; Maini, L; Chem. Com. 46, 6232-6242

(52) Tchertanov, L.; Pascard, C. Acta Crystallog. 1997, B53, 904-915.

(53) Lommerse, J. P.M.; Cole, J. C. Acta Crystallog. 1998, B54, 316-319.

(54) Steiner, T. J. Phys. Chem. 1998, A102, 7041-7052.

(55) Taylor, R.; Kennard, O. J. Am. Chem. Soc. 1982, 104, 5063-5070. 
(56) a) Desiraju. G.R.; Steiner, T. The weak hydrogen bond in stuctural chemistry and biology, Oxford University Press,1999, b) Desiraju, G. R. Acc. Chem. Res. 1996, 29, $441-449$.

(57) a) Takahashi, O.; Kohno, Y.; Nishio, M.; Chem. Rev. 2010, 110, 6049-6076 b) http://www.tim.hi-ho.ne.jp/dionisio

(58) Bogdanović, A.G.; Spasojević-de Biré, A.; Zarić,D.S. Eur. J. Inorg. Chem. 2002, $1599-1602$.

(59) Price, S. L. Advanced Drug Delivery Reviews 2004, 56, 301-319.

(60) Lewis, T. C.; Tocher, D. A.; Price, S. L. Crystal growth \& Design 2005, 5, 983-993.

(61) Price, S. L. Acc. Chem. Res. 2009, 42, 117-126.

(62) Issa, N.; Karamertzanis, P. G.; Welch, G. W. A.; Price, S. L. Crystal growth \& Design 2009, 9, 442-453.

(63) Ferreira da Silva, J.L.; Minas da Piedade, M.F.; Duarte, M.T. Inorg. Chim. Acta 2003, 356, 222-242.

(64) ICSD, Karlsruhe, Fachinformationszentrum (FIZ) Karlsruhe (2007)

(65) Berman, H.M.; Westbrook, J.; Feng, Z., Gilliland, G.; Bhat, T.N. ; Weissig, H. ; Shindyalov, I.N. ; Bourne P.E. 2000 Nucleic Acids Res., 28, 235-242 www.pdb.org.

(66) Bogdanović,G. A.; Bošnjaković-Pavlović, N.; Spasojević-de Biré, A.; Ghermani, N. E.; Mioč,. J. Serb. Chem. Soc. 2007, 72, 545-554.

(67) a) Yraola, F.; Albericio, F.; Royo, M.; Solans, X. Z. Kristallogr. New Cryst. Struct. 2008, 223, 45-47, b) Pacigova, S.; Rakovsky, E.; Sivak, M.; Zak, Z. Acta Crystallogr. 2007, C63, m419-m422, c) Zhu, C. Y.; Li, Y. T.; Wu, J. D.; Wu, Z. Y.; Wu, X. Acta Crystallogr. 2007, E63, m1777-u1733, d) Zhu, C. Y.; Li, Y. T.; Wu, Z. Y.; Xiao, N. Y. 
Acta Crystallogr. 2007, E63, m547-m549, e) Gong, Y.; Hu, C.; Li, H.; Tang, W.; Huang, K.; Hou, W. J. Mol. Struct. 2006, 784, 228-238, f) Rakovský, E.; Gyepes, R. Acta Crystallogr. 2006, E62, m2108-m2010, g) Zhao, Q. H.; Du, L.; Fang, R. B. Acta Crystallogr. 2006, E62, m360-m362, h) Zhu, C. Y.; Li, Y. T.; Wu, Z. Y.; Jiang, M. Acta Crystallogr. 2006, E62, m3092-m3095, i) Chen, L.; Lin, Z. Z.; Jiang, F. L.; Yuan, D. Q.; Hong, M. C. Chin. J. Struct. Chem. 2005, 24, 1186-1192, j) Correia, I.; Avecilla, F.; Marcao, S.; Pessoa, J. C. Inorg. Chim. Acta 2004, 357, 4476-4487, k) Li, G. B.; Yang, S. H.; Xiong, M.; Lin, J. H. Acta Crystallogr. 2004, C60, m612-m614, 1) Liu, S. X.; Zhai, H. J.; Peng, J.; Li, D. H.; Dai, Z. M.; Wang, E. B.; Hu, N. H.; Jia, H. Q. Chem. J. Chin.Univ. Chin. 2004, 25, 997-1001, m) Lee, U.; Jung, Y. H.; Joo, H. C.; Park, K. M. Acta Crystallogr. 2003, E59, m421-m424, n) Rehder, D.; Wang, D. Private Communication (CSD) 2003, o) Zhang, X. M.; Chen, X. M. Inorg. Chem. Commun. 2003, 6, 206-209, p) Sharma, S.; Ramanan, A.; Zavalij, P. Y.; Whittingham, M. S. Cryst. Eng. Comm 2002, 4, 601-604, q) Bukietynska, K.; Krot, K.; Starynowicz, P. Transition Met. Chem. 2001, 26, 311-314, r) Khan, M. I.; Tabussum, S.; Zheng, C. Synt. React. Inorg. Met. Org. Chem. 2000, 30, 1773-1790., s) Shan, Y.; Huang, S. D. J. Chem. Cryst. 1999, 29, 93-97, t) Pessoa, J. C.; Duarte, M. T.; Gillard, R. D.; Madeira, C.; Matias, P. M.; Tomaz, I. J. Chem. Soc., Dalton Trans. 1998, 28, 4015-4020, u) Janauer, G. G.; Dobley, A. D.; Zavalij, P. Y.; Whittingham, M. S. Chem. Mater. 1997, 9, 647-649, v) Zavalij, P. Y.; Chirayil, T.; Whittingham, M. S. Z. Kristallogr. New Cryst. Struct. 1997, 212, 321-322, w) Ninclaus, C.; Riou, D.; Férey, G. Acta Crystallogr. 1996, C52, 512514, x) Averbuch-Pouchot, M. T.; Durif, A. Z. Kristallogr. 1995, 210, 156-157, у) 
Averbuch-Pouchot, M. T. Z. Kristallogr. 1995, 210, 371-372, z) Averbuch-Pouchot, M. T.; Durif, A. Eur. J. Solid State Inorg. Chem. 1994, 31, 351-36, aa) Wang, X.; Liu, H. X.; Xu, X. X.;You, X. Z. Polyhedron 1993, 12, 77-81.

(68) a) CSDS v531/ConQuest 1.12 1. b) Allen, F. H., Lipscomb, K. J. and Battle, a. G. (2008) in Handbook of Chemoinformatics: From Data to Knowledge in 4 Volumes (ed J. Gasteiger), Wiley-VCH Verlag GmbH, Weinheim, Germany.

(69) a) Lee, U.; Acta, M. Acta Crystallogr. 2006, E62, i176-i178, b) Ksiksi, R.; Graia, M.; Jouini, T. Acta Crystallogr. 2005, E61, i177-i179, c) Ma, C. A.; Xie, A. L.; Wang, L. B. Acta Crystallogr. 2005, E61, i185-i187, d) Iida, A.; Ozeki, T. Acta Crystallogr. 2004, C60, i43-i46, e) Ksiksi, R.; Graia, M.; Driss, A.; Jouini, T. Acta Crystallogr. 2004, E60, i105-i107, f) Iida, A.; Ozeki, T. Acta Crystallogr. 2003, C59, i41-i44, g) Lee, U.; Joo, H. C. Acta Crystallogr. 2003, E59, i122-1124, h) Fratzky, D.; Schneider, M.; Rabe, S.; Meisel Crystallogr. 2000, C56, 740-741, i) Matias, M.; Pessoa, J.; Duarte, M.; Madeira, C. Acta Cryst. 2000, 56, 275-276, j) Baudrin, E.; Denis, S.; Touboul, M.; Nowogrocki, G. Eur. J. Solid State Inorg. Chem. 1997, 34, 1011-1026; k) Avtamonova, N. V.; Trunov, V. K.; Makarevich, L. G. Izvest. Aka. Nauk Sssr Neorg. Mater. 1990, 26, 350-356.

(70) Varetto, U.; Swiss National Supercomputing Centre: Manno (Switzerland) MOLEKEL version 5.4.0.8

(71) Felts, L. R.; Reilly, J.T.; Tanner, J.J. J. Biol. Chem. 2006, 281, 30289-30298.

(72) Bae, J. H.; Lew, E.D.; Yuzawa, S.; Tome, F.; Lax, I.; Schlessinger, J. Cell (Cambridge, Mass.) 2009, 138, 514-524.

(73) a) Maciejewska, G.; Nosek, M.; Glovyak, T.; Starosta, J.; Cieslak-Golonka, M. Polyhedron 2003, 22, 1415 -1423, b) Higami, T.; Hashimoto, M.; Okeya, S. Acta Cryst. 
2002, C58, i144-i146, c) Sun, Z.G.; Long, L. S.; Ren, Y. P.; Huang, R. B.; Zheng, L. S.; Ng, S.W. Acta Cryst. 2002, E58, i34-i36, d) Khan, M. I.; Tabussum, S.; Zheng, C.; Journal Cluster Science, 2001, 12, 583-594, e) Rastsvetaeva, R.K.; Kristallografiya 1999, 44, 6, 1027-1028, f) Xu, J.N.; Yang, G.Y.; Sun, H.R.; Wang, T.-G.; Xu, J.Q.; Wu, Q.J. Jiegon Huaxue 1996, 15, 253-256, g) Griffen, D.T.; Brigham Young University Geology Studies 1990, 36, 1-14, h) Durif, A.; Averbuch-Pouchot, M.T.; Guitel, J.C. Acta Cryst. 1980, B36, 680-982, i) Swallow, A.G.; Ahmed, F.R.; Barnes W.H. Acta Cryst. 1966, 21, 397-405, j) Evans, H.T. Inorg.Chem. 1966, 5, 967-977. 


\section{Figure captions}

Figure 1. $\mathrm{V}_{10}$ atom labelling.

Figure 2. Schematic representation of the main expected non covalent interactions with $\mathrm{V}_{10}$ anion according to ref 39 . a) strong interactions such as $\mathrm{O}-\mathrm{H} \cdots \mathrm{O}_{\mathrm{dv}}$ or $\mathrm{N}-\mathrm{H} \cdots \mathrm{O}_{\mathrm{dv}}$ b) weak interactions such as $\mathrm{C}-\mathrm{H} \cdots \mathrm{O}_{\mathrm{dv}}$ or cation interactions. $\mathrm{V}_{10} 3 \mathrm{D}$ isodensity surface $\left(0.007\right.$ e. $\left.\AA^{-3}\right)$ colored by the electrostatic potential values $\left(\mathrm{e} . \AA^{-1}\right)$

Figure 3. Distribution of the $\mathrm{D} \cdots \mathrm{O}$ distances and $\mathrm{D}-\mathrm{H} \cdots \mathrm{O}_{\mathrm{dv}}$ angles. a and b) $\mathrm{O}-\mathrm{H} \cdots \mathrm{O}_{\mathrm{dv}}, \mathrm{c}$ and d) $\mathrm{N}-\mathrm{H} \cdots \mathrm{O}_{\mathrm{dv}}$, e and f) $\mathrm{C}-\mathrm{H} \cdots \mathrm{O}_{\mathrm{dv}}$ interactions

Figure 4. Distribution of the $\mathrm{D}-\mathrm{H} \cdots \mathrm{O}_{\mathrm{dv}}$ angles versus the $\mathrm{H} \cdots \mathrm{O}_{\mathrm{dv}}$ distances according to the oxygen atom type for each donor type; a) $\mathrm{O}-\mathrm{H} \cdots \mathrm{O}_{\mathrm{dv}}$ interactions, b) $\mathrm{N}-\mathrm{H} \cdots \mathrm{O}_{\mathrm{dv}}$ interactions and c) $\mathrm{C}-\mathrm{H} \cdots \mathrm{O}_{\mathrm{dv}}$ interactions.

Figure 5. Frequency of each type of interaction for each oxygen atom type: a) normalization by the number of interaction type; b) normalized by the occurrence of $\mathrm{O}_{\mathrm{dv}}$ type; c) normalization by the number of bonds type.

Figure 6. Number of contacts for each oxygen atom type: all contacts (red), all contacts for binded oxygen atom (green), contacts from monofurcated protons (blue). 
Figure 7. Distribution of $\gamma$ angle and distance $\mathrm{O}_{\mathrm{dv}} \cdots \mathrm{H}$ according to the oxygen atom type for each donor type for: a) $\mathrm{O}-\mathrm{H} \cdots \mathrm{O}_{\mathrm{dv}}$ interactions, b) $\mathrm{N}-\mathrm{H} \cdots \mathrm{O}_{\mathrm{dv}}$ interactions and c) $\mathrm{C}-\mathrm{H} \cdots \mathrm{O}_{\mathrm{dv}}$ interactions.

Figure 8. Frequency of the proton position in the $\mathrm{O}_{\mathrm{dv}}$ neighbourhood for $\mathrm{D}-\mathrm{H} \cdots \mathrm{O}_{\mathrm{dv}}$ interactions according to the donor type for each oxygen atom type: a) $\mathrm{Ob}$ and b) $\mathrm{Og}$. The number of interactions considered is written on each stick. The number of identical sectors is taken into account.

Figure 9. a) Interactions between $\mathrm{V}_{10}$ anion and protein. a) PDB Id 2d1g. N-H $\cdots \mathrm{O}$ contact in the asymmetric unit. The 3 histidine groups (HIS495, HIS 496, HIS497) and the lysine (LYS394) are indicated. b) PDB Id 3gqi N-H... contact in the asymmetric unit. The asparagine (ASN506), aspartic acid (ASP503) and arginine (ARG507) are indicated. 


\section{Table captions}

Table 1. Molecule structures used in this manuscript. In case of decavanadate - cation interaction the oxygen type engaged in the interaction is indicated.

Table 2. Hydrogen bonds between $\mathrm{V}_{10}$ and protein from 2d1g and 3gqi structures. Distances $d(D \ldots O) \leq 3.20 \AA$ have been reported. 


\section{Figure 1}

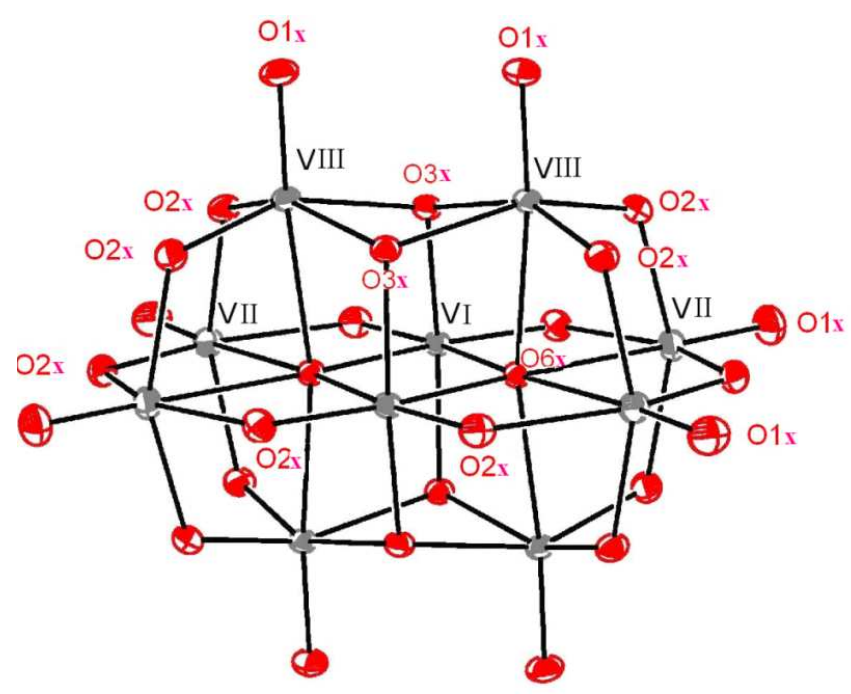

a)

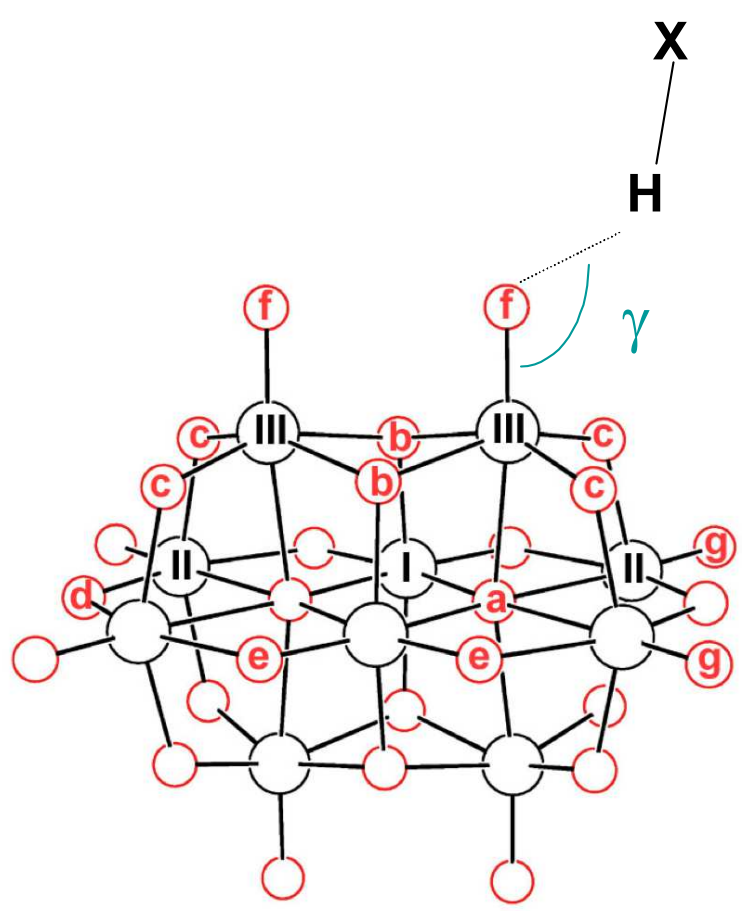

b) 


\section{Figure2}
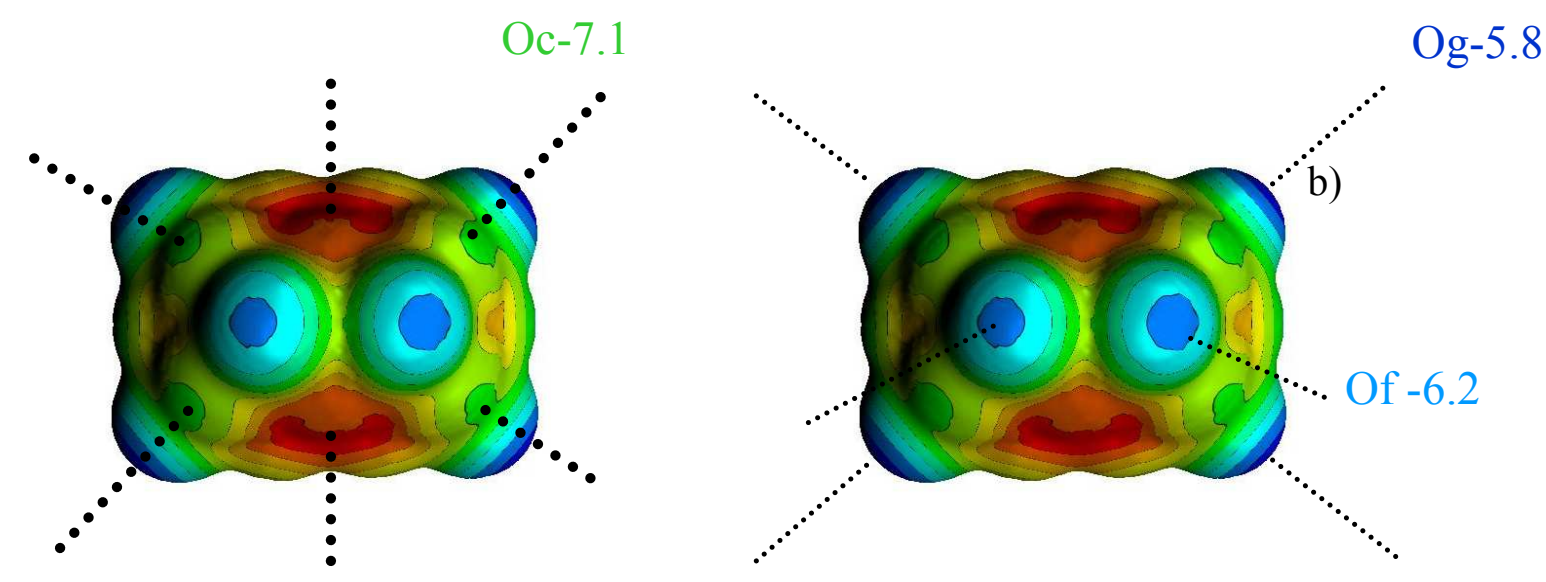

$\mathrm{Ob}-8.7$ 
Figure 3

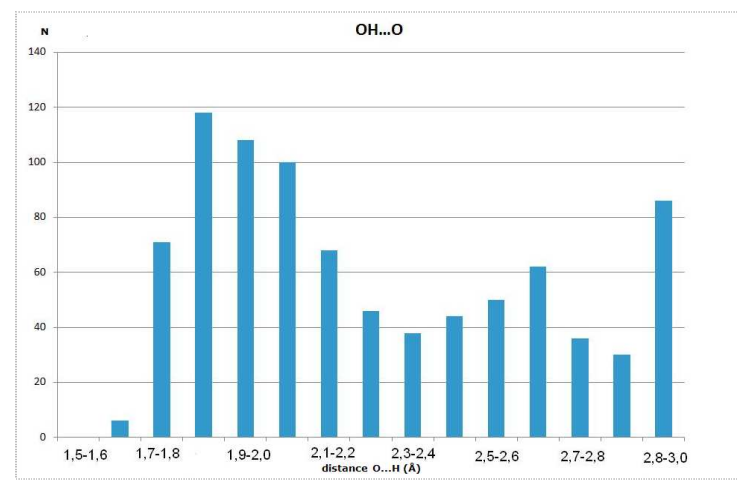

a)

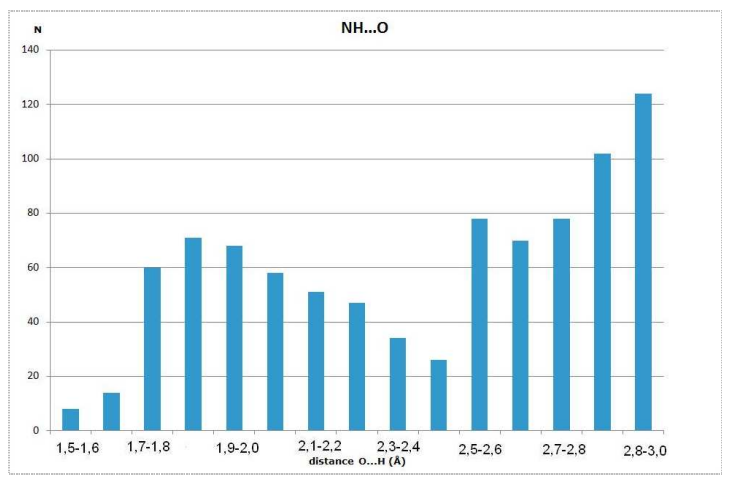

c)

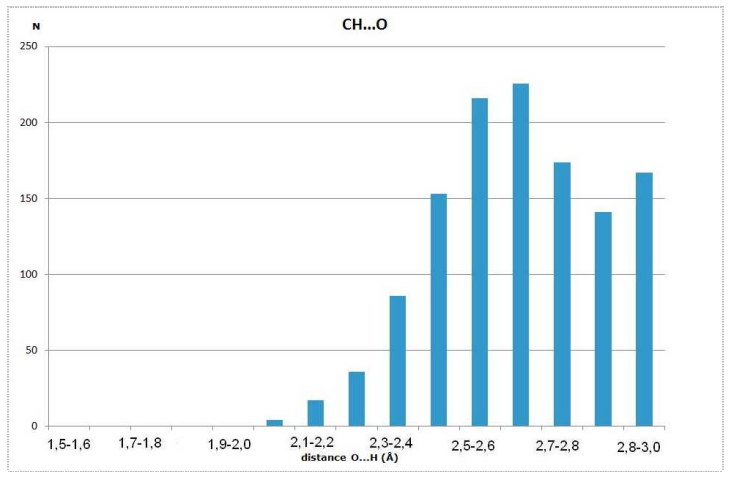

e)

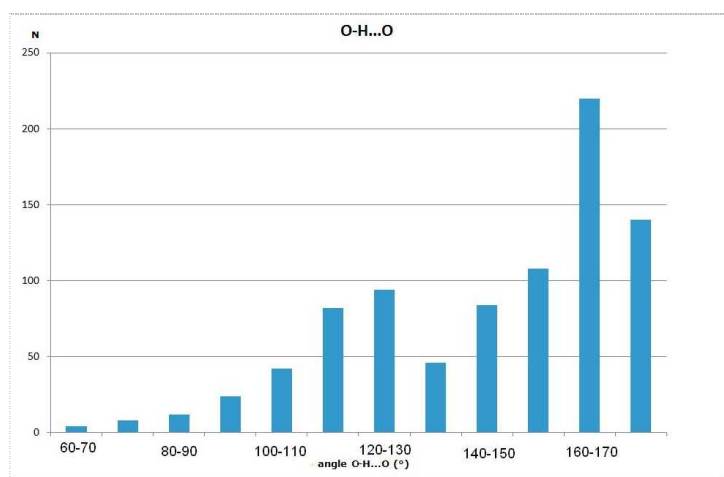

b)

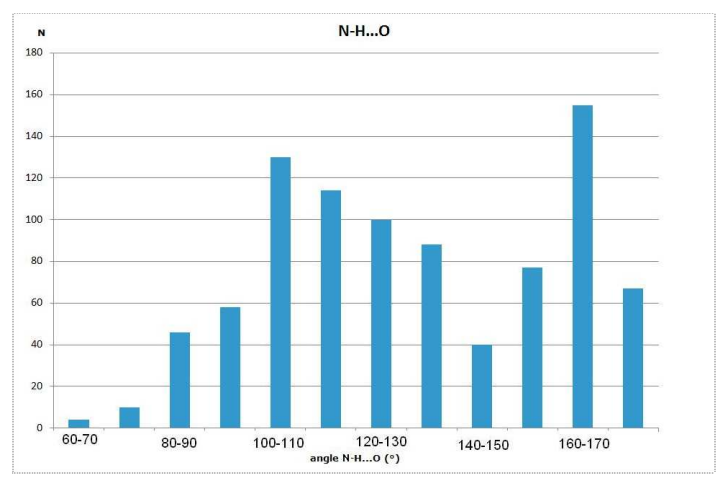

d)

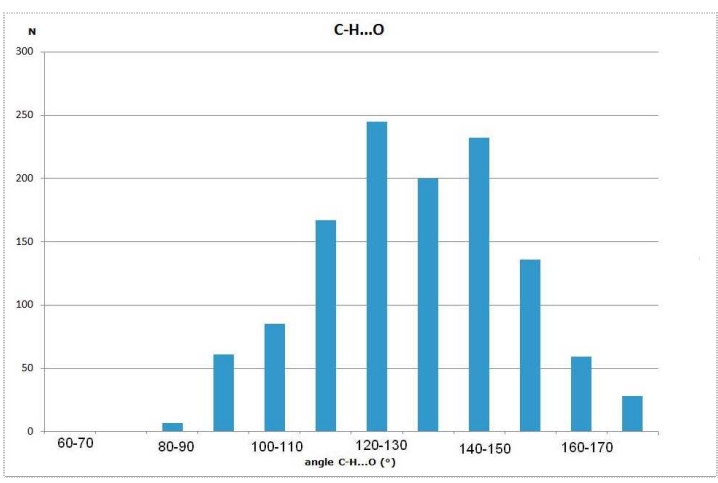

f) 


\section{Figure 4}

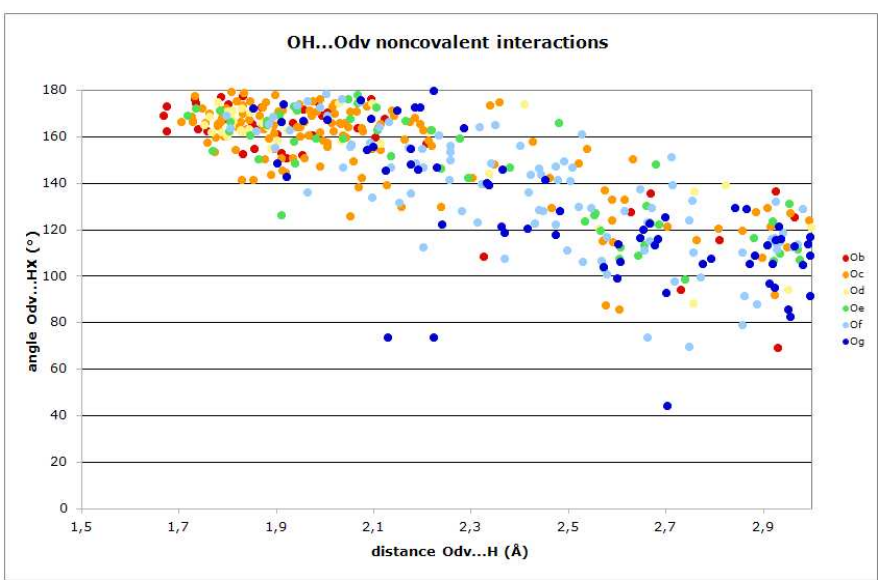

a)

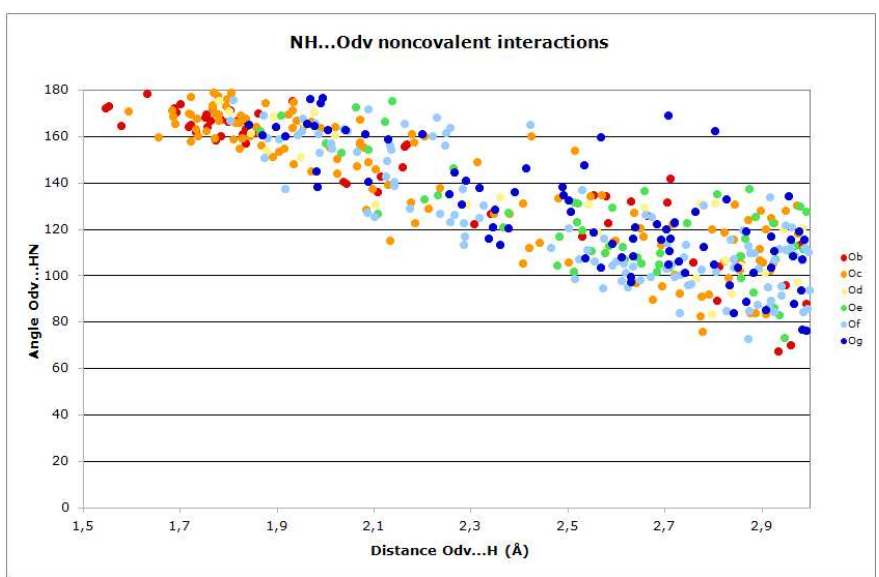

b)

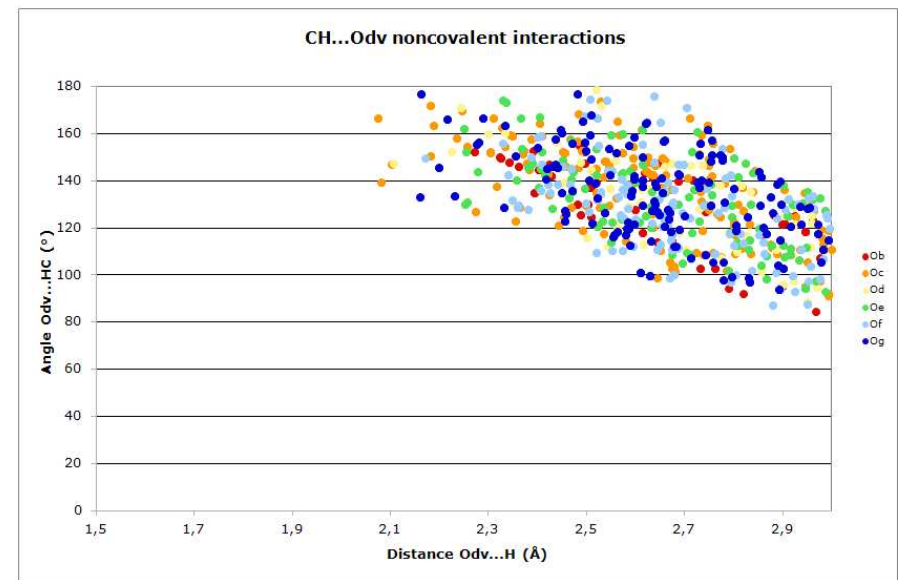

c) 
Figure 5

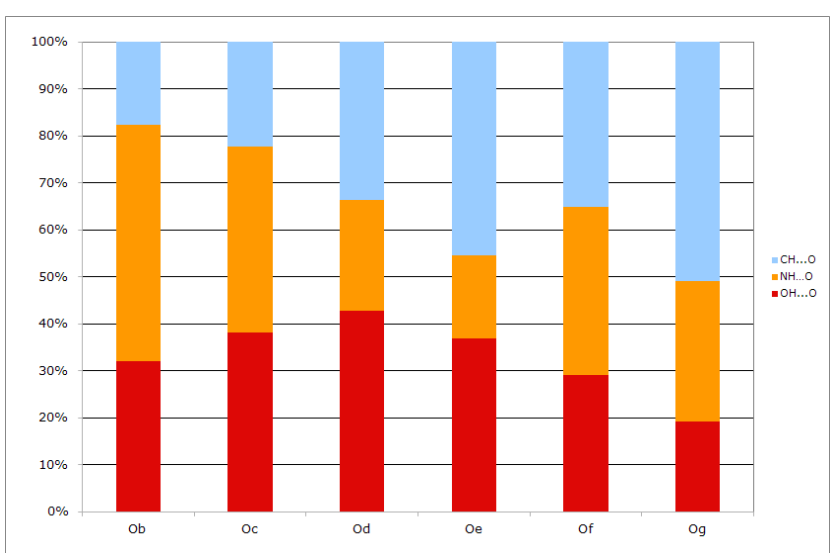

a)

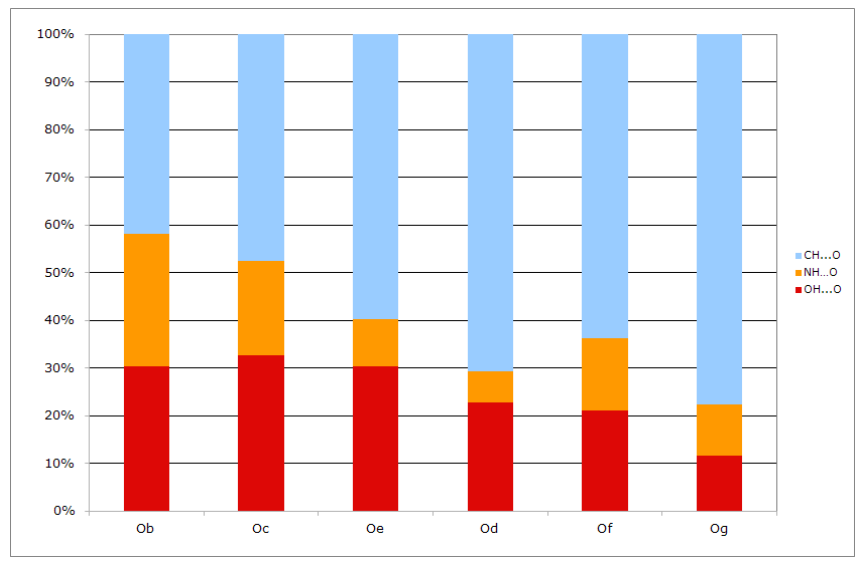

b)

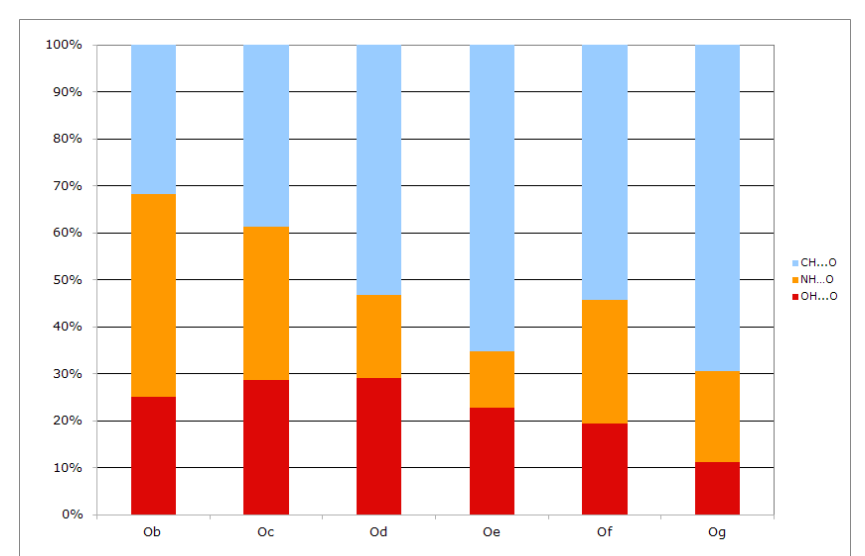

c) 
Figure 6

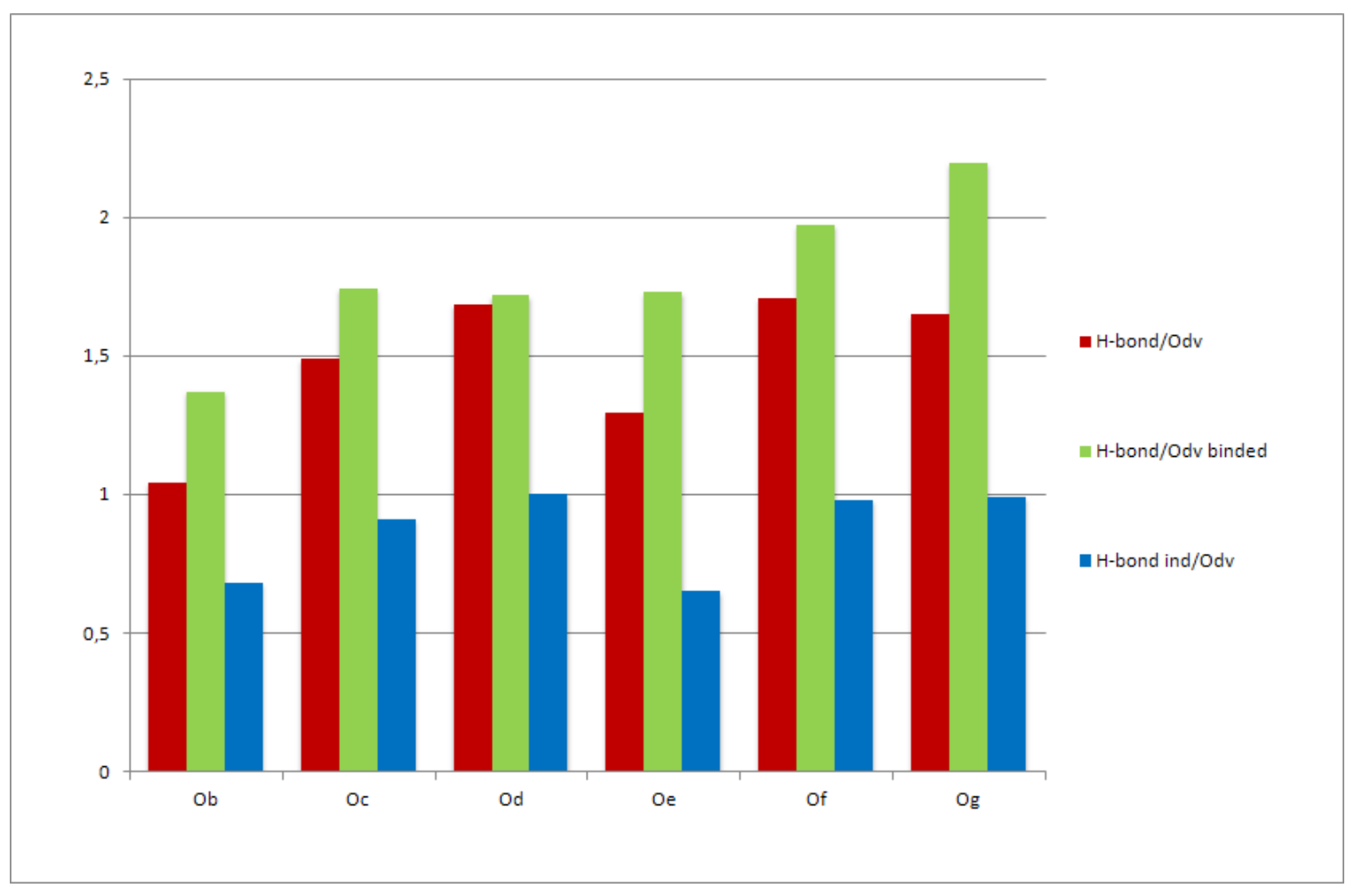

1

3

4

5

6

7

8

9

10

11

12

13

14

15

16

17

18

19

20

21

22

23

24

25

26

27

28

29

30

31

32

33

34

35

36

37

38

39

40

41

42

43

44

45

46

47

48

49

50

51

52

53

54

55

56

57

58

59

60 


\section{Figure 7}

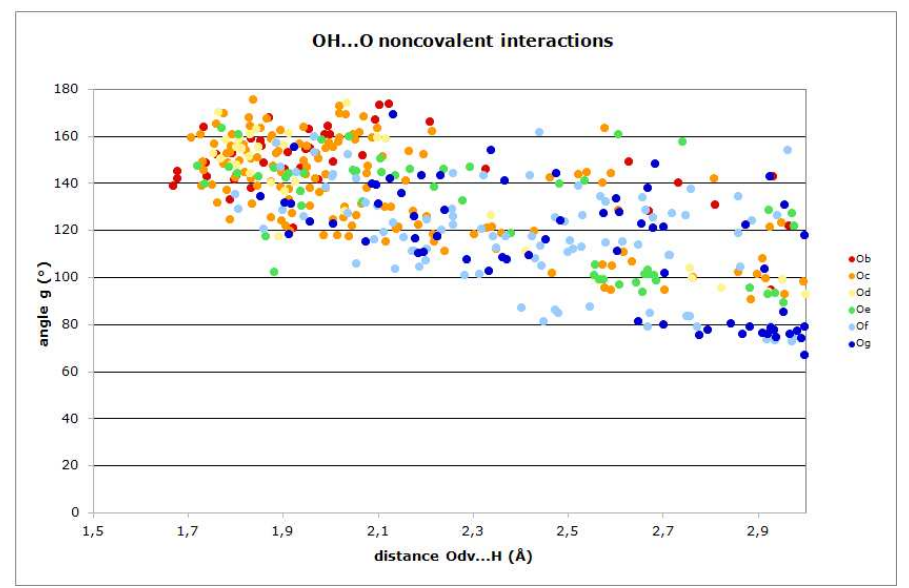

a)

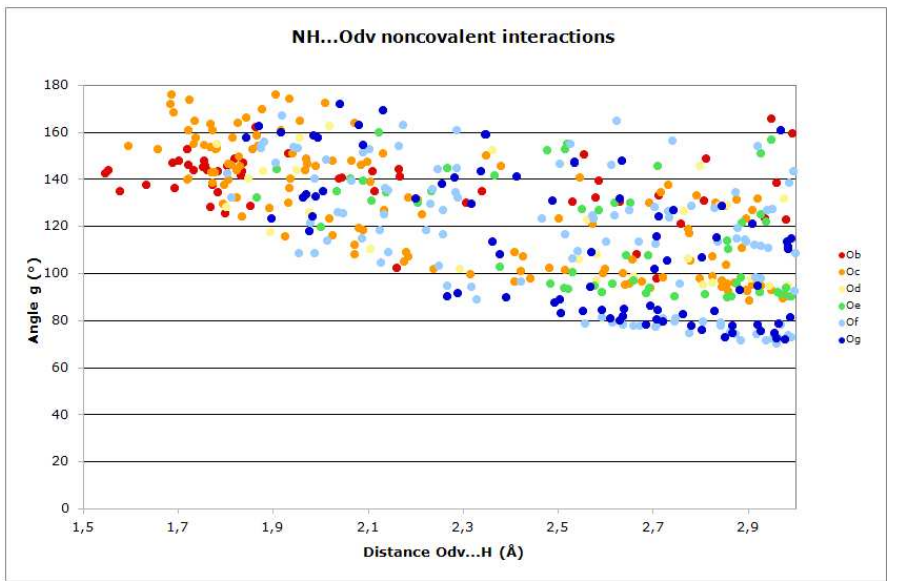

b)

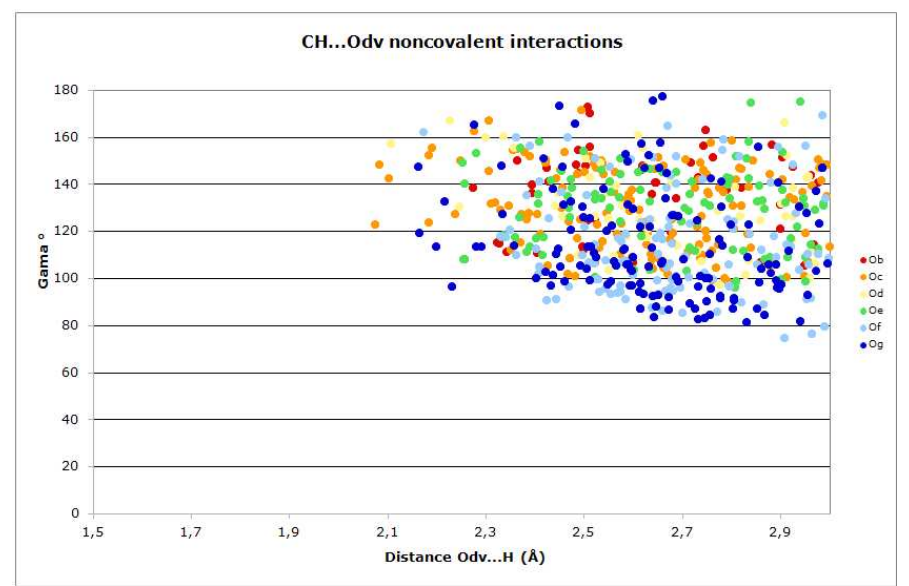

c)

ACS Paragon Plus Environment 


\section{Figure 8}
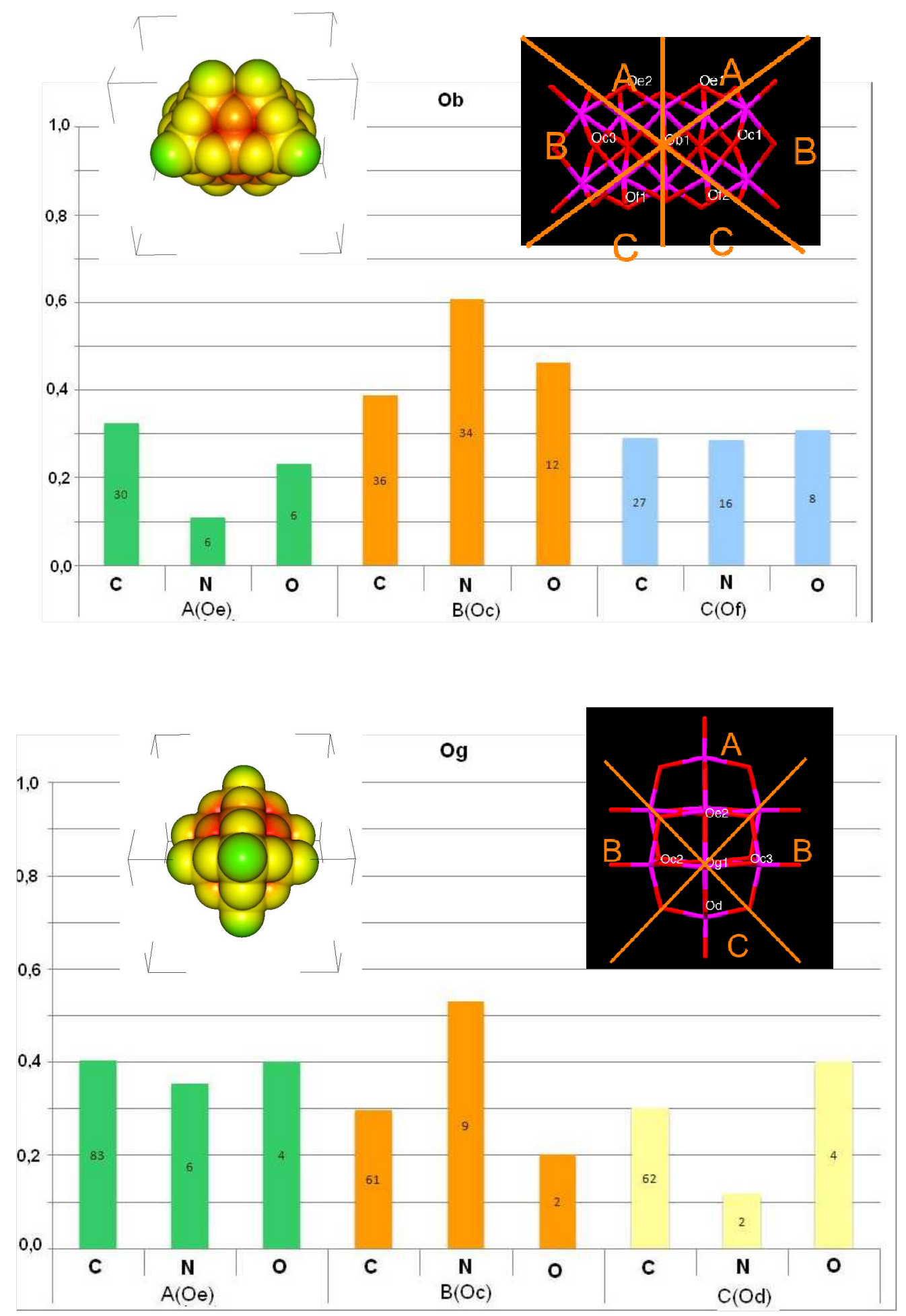

b 


\section{Figure 9}

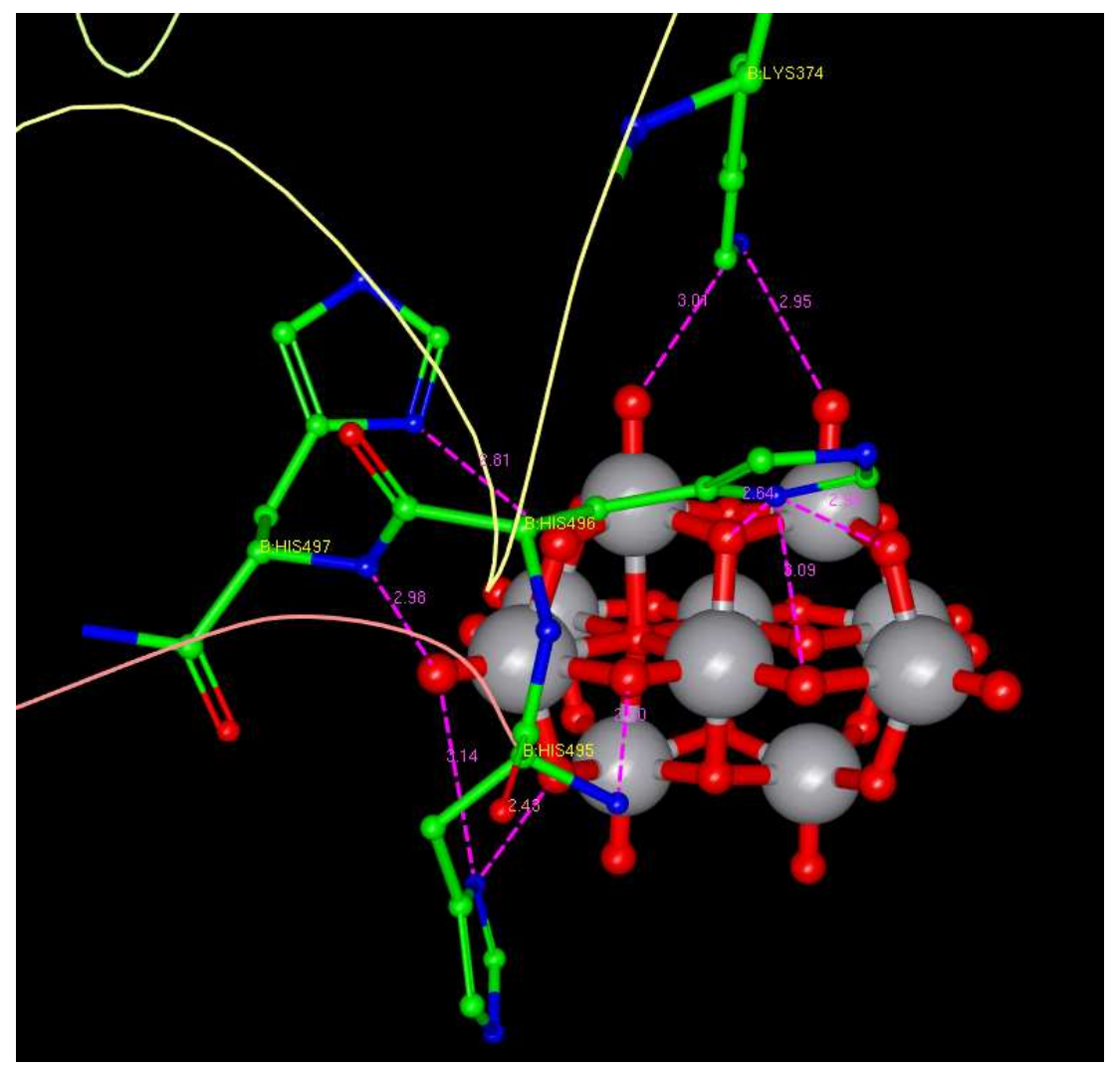

a)

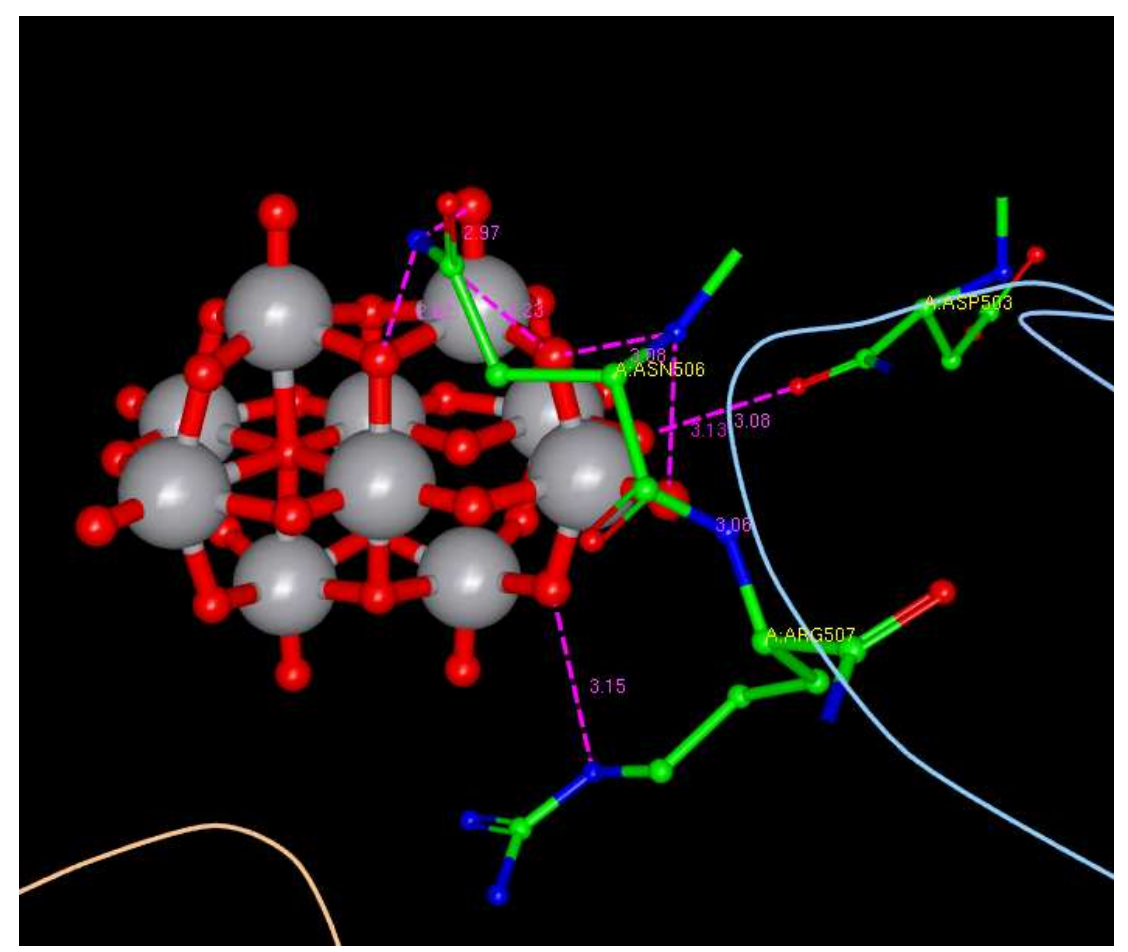

b) 
Table 1.

\begin{tabular}{|c|c|c|c|c|}
\hline $\begin{array}{c}\text { Oxygen } \\
\text { type }\end{array}$ & Cation & Formula & \begin{tabular}{|c|} 
CSD \\
REFCODE \\
or ICSD Id \\
or PDB Id \\
\end{tabular} & Reference \\
\hline \multicolumn{5}{|c|}{ Organic compounds } \\
\hline \multirow[t]{11}{*}{ Of } & $\mathrm{Na}$ & $\mathrm{Na}_{3}\left[\mathrm{~V}_{10} \mathrm{O}_{28}\right]\left(\mathrm{C}_{4} \mathrm{~N}_{3} \mathrm{OH}_{5}\right)_{3}\left(\mathrm{C}_{4} \mathrm{~N}_{3} \mathrm{OH}_{6}\right)_{3} \cdot 10 \mathrm{H}_{2} \mathrm{O}$ & & 42 \\
\hline & & $\left(\mathrm{C}_{8} \mathrm{~F} \mathrm{~N} \mathrm{H}_{11}\right)_{6}\left[\mathrm{~V}_{10} \mathrm{O}_{28}\right] 4 \mathrm{H}_{2} \mathrm{O}$ & DIWYIS & $67 \mathrm{a}$ \\
\hline & & $\left(\mathrm{C}_{6} \mathrm{H}_{7} \mathrm{~N}_{2} \mathrm{O}\right)_{6}\left[\mathrm{~V}_{10} \mathrm{O}_{28}\right] 2 \mathrm{H}_{2} \mathrm{O}$ & DIKREV & $67 \mathrm{~b}$ \\
\hline & & $\left(\mathrm{C}_{7} \mathrm{~N} \mathrm{H}_{10}\right)_{6}\left[\mathrm{~V}_{10} \mathrm{O}_{28}\right] 2 \mathrm{H}_{2} \mathrm{O}$ & WILWUK & 22 \\
\hline & & $\left.3\left[\mathrm{C}_{5} \mathrm{H}_{16} \mathrm{~N}_{2}\right)^{2+}\right]\left[\mathrm{V}_{10} \mathrm{O}_{28}\right] 6 \mathrm{H}_{2} \mathrm{O}$ & GIHCAC & $67 \mathrm{c}$ \\
\hline & & $\left(\mathrm{C}_{4} \mathrm{H}_{14} \mathrm{~N}_{2}\right)_{3}\left[\mathrm{~V}_{10} \mathrm{O}_{28}\right] 5 \mathrm{H}_{2} \mathrm{O}$ & JEWCOE & $67 d$ \\
\hline & & $\left(\mathrm{C}_{5} \mathrm{H}_{7} \mathrm{~N}_{2}\right)_{6}\left[\mathrm{~V}_{10} \mathrm{O}_{28}\right] 2 \mathrm{H}_{2} \mathrm{O}$ & DEFPIO & $67 \mathrm{e}$ \\
\hline & & $\left.\left[\mathrm{C}_{4} \mathrm{H}_{14} \mathrm{~N}_{2}\right)_{3}\right]\left[\mathrm{V}_{10} \mathrm{O}_{28}\right] 6 \mathrm{H}_{2} \mathrm{O}$ & MENSAA & $67 \mathrm{f}$ \\
\hline & & $\left.\left[\mathrm{C}_{3} \mathrm{H}_{12} \mathrm{~N}_{2}\right)_{2}\right]\left[\mathrm{Cu}\left(\mathrm{H}_{2} \mathrm{O}\right)_{6}\right]\left[\mathrm{V}_{10} \mathrm{O}_{28}\right] \cdot 7 \mathrm{H}_{2} \mathrm{O}$ & YEDZOX & $67 \mathrm{~g}$ \\
\hline & & $\left(\mathrm{C}_{3} \mathrm{~N}_{2} \mathrm{H}_{12}\right)_{3}\left[\mathrm{~V}_{10} \mathrm{O}_{28}\right] 5.5 \mathrm{H}_{2} \mathrm{O}$ & QERQEK & $67 \mathrm{~h}$ \\
\hline & & $\left(\mathrm{C}_{4} \mathrm{H}_{12} \mathrm{~N} \mathrm{O}\right)_{6} 2\left(\mathrm{C}_{3} \mathrm{H}_{8} \mathrm{O}\right)\left[\mathrm{V}_{10} \mathrm{O}_{28}\right] 2 \mathrm{H}_{2} \mathrm{O}$ & VAXJUA & $67 \mathrm{i}$ \\
\hline \multirow[t]{13}{*}{$\mathbf{O g}$} & $\mathrm{K}$ & {$\left[\mathrm{V}_{10} \mathrm{O}_{28}\right]\left(\mathrm{C}_{2} \mathrm{H}_{10} \mathrm{~N}_{2}\right)_{2} \mathrm{~K}_{2} 4 \mathrm{H}_{2} \mathrm{O}$} & JAJYOJ & $67 \mathrm{j}$ \\
\hline & & {$\left[\mathrm{C}_{2} \mathrm{H}_{10} \mathrm{~N}_{2}\right)_{2}\left[\mathrm{Na}_{2}\left(\mathrm{H}_{2} \mathrm{O}\right)_{10}\right]\left[\mathrm{V}_{10} \mathrm{O}_{28}\right]$} & MAJKUE & $67 \mathrm{k}$ \\
\hline & & $\left(\mathrm{C}_{6} \mathrm{H}_{14} \mathrm{~N}_{5} \mathrm{O}\right)_{6}\left[\mathrm{~V}_{10} \mathrm{O}_{28}\right] 6 \mathrm{H}_{2} \mathrm{O}$ & FESYUY & 671 \\
\hline & & {$\left[\mathrm{H}_{12} \mathrm{CoO}_{6}\right]_{3}\left[\mathrm{~V}_{10} \mathrm{O}_{28}\right]\left[\mathrm{C}_{12} \mathrm{H}_{24} \mathrm{O}_{6}\right]_{2} \cdot 10 \mathrm{H}_{2} \mathrm{O}$} & AJETEO & $67 \mathrm{~m}$ \\
\hline & & $\left(\mathrm{C}_{14} \mathrm{H}_{30} \mathrm{~N}_{2} \mathrm{O}_{4}\right)_{2}\left[\mathrm{~V}_{10} \mathrm{O}_{28}\right] 6 \mathrm{H}_{2} \mathrm{O}$ & HABYIT & $67 \mathrm{n}$ \\
\hline & & $\mathrm{C}_{20} \mathrm{H}_{48} \mathrm{~N}_{4} \mathrm{O}_{16} \mathrm{Zn}_{2} 2\left[\mathrm{NH}_{4}\right]\left[\mathrm{V}_{10} \mathrm{O}_{28}\right] \cdot 6 \mathrm{H}_{2} \mathrm{O}$ & WUNNEY & $67 \mathrm{o}$ \\
\hline & & $\mathrm{C}_{20} \mathrm{H}_{48} \mathrm{~N}_{4} \mathrm{O}_{16} \mathrm{Mn}_{2} 2\left[\mathrm{NH}_{4}\right]\left[\mathrm{V}_{10} \mathrm{O}_{28}\right] \cdot 6 \mathrm{H}_{2} \mathrm{O}$ & WUNNIC & $67 \mathrm{o}$ \\
\hline & & $\left(\mathrm{C}_{24} \mathrm{H}_{20} \mathrm{As}\right)_{2}\left(\mathrm{C}_{4} \mathrm{H}_{10} \mathrm{~N} \mathrm{O}\right)_{4}\left[\mathrm{~V}_{10} \mathrm{O}_{28}\right] 4 \mathrm{H}_{2} \mathrm{O}$ & UHEBOY & $67 \mathrm{p}$ \\
\hline & & {$\left[\mathrm{C}_{2} \mathrm{H}_{8} \mathrm{~N}\right]_{6}\left[\mathrm{~V}_{10} \mathrm{O}_{28}\right] \cdot \mathrm{H}_{2} \mathrm{O}$} & QETZOE & $67 \mathrm{q}$ \\
\hline & & $\left.\mathrm{Na}\left[\mathrm{H}_{3} \mathrm{~N}\right]\left[\mathrm{CH}_{2}\right)_{2} \mathrm{NH}_{3}\right)_{2.5}\left[\mathrm{~V}_{10} \mathrm{O}_{28}\right] \cdot 5 \mathrm{H}_{2} \mathrm{O}$ & XISGUB & $67 \mathrm{r}$ \\
\hline & & {$\left[\mathrm{C}_{4} \mathrm{H}_{12} \mathrm{~N}\right]_{2}\left[\mathrm{H}_{12} \mathrm{Mn} \mathrm{O}_{6}\right]_{2}\left[\mathrm{~V}_{10} \mathrm{O}_{28}\right] \cdot 2 \mathrm{H}_{2} \mathrm{O}$} & LALVUP & $67 \mathrm{~s}$ \\
\hline & & {$[\mathrm{Hpy}+] 4\left[\mathrm{C}_{14} \mathrm{H}_{13} \mathrm{~N}_{2}\right]_{2}\left[\mathrm{~V}_{10} \mathrm{O}_{28}\right]$} & GOPDOE & $67 \mathrm{t}$ \\
\hline & & {$\left[\mathrm{Li}\left(\mathrm{H}_{2} \mathrm{O}\right)_{4}\right]_{2}\left[\mathrm{~N}\left(\mathrm{CH}_{3}\right)_{4}\right]_{4}\left[\mathrm{~V}_{10} \mathrm{O}_{28}\right] \cdot 4 \mathrm{H}_{2} \mathrm{O}$} & NONKUW & $67 \mathrm{u}$ \\
\hline \multirow[t]{5}{*}{ Of,Og } & $\mathrm{Na}$ & {$[\mathrm{Na}]_{4}\left[\mathrm{~N}\left(\mathrm{CH}_{4}\right)_{4}\right]_{4}\left[\mathrm{~V}_{10} \mathrm{O}_{28}\right] \cdot 20 \mathrm{H}_{2} \mathrm{O}$} & TIPWOE & $67 \mathrm{v}$ \\
\hline & & {$\left[\mathrm{C}_{2} \mathrm{H}_{10} \mathrm{~N}_{2}\right]_{3}\left[\mathrm{~V}_{10} \mathrm{O}_{28}\right] \cdot 2 \mathrm{H}_{2} \mathrm{O}$} & ZOZBIZ & $67 \mathrm{w}$ \\
\hline & & $\left(\mathrm{C}_{2} \mathrm{H}_{8} \mathrm{~N} \mathrm{O}\right)_{6}\left[\mathrm{~V}_{10} \mathrm{O}_{28}\right] 6 \mathrm{H}_{2} \mathrm{O}$ & YUFFUA & $67 x$ \\
\hline & & $\left(\mathrm{C}_{4} \mathrm{H}_{12} \mathrm{~N} \mathrm{O}\right)_{6}\left[\mathrm{~V}_{10} \mathrm{O}_{28}\right]$ & YUFTAU & $67 y$ \\
\hline & & $\left(\mathrm{C}_{3} \mathrm{H}_{10} \mathrm{~N}\right)_{6}\left[\mathrm{~V}_{10} \mathrm{O}_{28}\right] 4 \mathrm{H}_{2} \mathrm{O}$ & HIDLEL & $67 \mathrm{z}$ \\
\hline
\end{tabular}




\begin{tabular}{|c|c|c|c|c|}
\hline & & $\left(\mathrm{NH}_{4}\right)_{6}(\text { Gly-Gly })_{2}\left[\mathrm{~V}_{10} \mathrm{O}_{28}\right] 4 \mathrm{H}_{2} \mathrm{O}$ & YETYIF & 36 \\
\hline & & $\left(\mathrm{C} \mathrm{H}_{6} \mathrm{~N}_{3}\right)_{6}\left[\mathrm{~V}_{10} \mathrm{O}_{28}\right] 6 \mathrm{H}_{2} \mathrm{O}$ & HAKYAT & $67 \mathrm{aa}$ \\
\hline \multicolumn{5}{|c|}{ Inorganic compounds } \\
\hline & & $\left(\mathrm{NH}_{4}\right)_{6}\left[\mathrm{~V}_{10} \mathrm{O}_{28}\right] \cdot 5 \mathrm{H}_{2} \mathrm{O}$ & & 66 \\
\hline Of, Og & $\mathrm{Na}$ & $\mathrm{Na}_{4} \mathrm{~K}_{2}\left[\mathrm{~V}_{10} \mathrm{O}_{28}\right] .18 \mathrm{H}_{2} \mathrm{O}$ & 249156 & $69 \mathrm{a}$ \\
\hline \multirow[t]{3}{*}{ Of } & $\mathrm{K}$ & $\mathrm{Na}_{4} \mathrm{~K}_{2}\left[\mathrm{~V}_{10} \mathrm{O}_{28}\right] \cdot 18 \mathrm{H}_{2} \mathrm{O}$ & 249156 & $69 a$ \\
\hline & & $\left(\mathrm{NH}_{4}\right)_{4} \mathrm{Li}_{2}\left[\mathrm{~V}_{10} \mathrm{O}_{28}\right] \cdot 10 \mathrm{H}_{2} \mathrm{O}$ & 59853 & $69 b$ \\
\hline & & {$\left[\mathrm{Li}_{6}\left(\mathrm{H}_{2} \mathrm{O}\right)_{16} \mathrm{~V}_{10} \mathrm{O}_{28}\right]_{n}$} & 170991 & $69 \mathrm{c}$ \\
\hline \multirow[t]{2}{*}{ Oc, Og } & $\mathrm{Na}$ & $\mathrm{Mg}_{2} \mathrm{Na}_{2}\left[\mathrm{~V}_{10} \mathrm{O}_{28}\right] \cdot 20 \mathrm{H}_{2} \mathrm{O}$ & 59839 & $69 \mathrm{~d}$ \\
\hline & & $\mathrm{Na}_{5.22} \mathrm{Li}_{0.78}\left[\mathrm{~V}_{10} \mathrm{O}_{28}\right] \cdot 20 \mathrm{H}_{2} \mathrm{O}$ & 170783 & $69 \mathrm{e}$ \\
\hline Og & $\mathrm{Na}$ & $\mathrm{Cu} \mathrm{Na}_{4}\left[\mathrm{~V}_{10} \mathrm{O}_{28}\right] \cdot 23 \mathrm{H}_{2} \mathrm{O}$ & 281319 & $69 \mathrm{f}$ \\
\hline \multirow[t]{2}{*}{ Of, Og } & $\mathrm{K}$ & $\mathrm{K}_{4} \mathrm{Na}_{2} \mathrm{~V}_{10} \mathrm{O}_{28} \cdot 10 \mathrm{H}_{2} \mathrm{O}$ & 281347 & $69 \mathrm{~g}$ \\
\hline & & {$\left[\mathrm{NH}_{4}\right]_{4} \mathrm{Na}_{2}\left[\mathrm{~V}_{10} \mathrm{O}_{28}\right] \cdot 10 \mathrm{H}_{2} \mathrm{O}$} & 280357 & $69 \mathrm{~h}$ \\
\hline \multirow[t]{3}{*}{ Oc,Og } & $\mathrm{K}$ & $\mathrm{K}_{4} \mathrm{Na}_{2}\left[\mathrm{~V}_{10} \mathrm{O}_{28}\right] .10 \mathrm{H}_{2} \mathrm{O}$ & 170750 & $69 \mathrm{i}$ \\
\hline & & {$\left[\mathrm{NH}_{4}\right]_{2}\left[\mathrm{Co}\left(\mathrm{H}_{2} \mathrm{O}\right)_{6}\right]_{2}\left[\mathrm{~V}_{10} \mathrm{O}_{28}\right] \cdot 4 \mathrm{H}_{2} \mathrm{O}$} & 84282 & $69 \mathrm{j}$ \\
\hline & & {$\left[\mathrm{NH}_{4}\right]_{2} \mathrm{Mg}_{2} \mathrm{~V}_{10} \mathrm{O}_{28} \cdot 16 \mathrm{H}_{2} \mathrm{O}$} & 39217 & $69 \mathrm{k}$ \\
\hline $\mathrm{Oc}, \mathrm{Og}$ & $\mathrm{Rb}$ & $\mathrm{Rb}_{2} \mathrm{Mg}_{2}\left[\mathrm{~V}_{10} \mathrm{O}_{28}\right] \cdot 16 \mathrm{H}_{2} \mathrm{O}$ & 39218 & $69 \mathrm{k}$ \\
\hline Oc,Og,Of & $\mathrm{K}$ & $\mathrm{K}_{2} \mathrm{Mg}_{2}\left[\mathrm{~V}_{10} \mathrm{O}_{28}\right] \cdot 16 \mathrm{H}_{2} \mathrm{O}$ & 39216 & $69 \mathrm{k}$ \\
\hline Oc, Of, Og & $\mathrm{K}$ & $\mathrm{K}_{2}\left(\mathrm{Co}\left(\mathrm{H}_{2} \mathrm{O}\right)_{6}\right)_{2}\left[\mathrm{~V}_{10} \mathrm{O}_{28}\right] \cdot 4 \mathrm{H}_{2} \mathrm{O}$ & 281298 & $69 \mathrm{~g}$ \\
\hline Of & $\mathrm{Na}$ & $\mathrm{Na}_{3}\left(\mathrm{NH}_{4}\right)_{3}\left[\mathrm{~V}_{10} \mathrm{O}_{28}\right] \cdot 12 \mathrm{H}_{2} \mathrm{O}$ & 412811 & $73 a$ \\
\hline Of & $\mathrm{Na}$ & {$\left[\mathrm{Ni}\left(\mathrm{H}_{2} \mathrm{O}\right)_{6}\right]_{2}\left[\mathrm{Na}(\mathrm{H} 2 \mathrm{O})_{3}\right] 2\left[\mathrm{~V}_{10} \mathrm{O}_{28}\right] \cdot 4 \mathrm{H}_{2} \mathrm{O}$} & 280901 & $73 b$ \\
\hline Of & $\mathrm{Na}$ & {$\left[\mathrm{Na}_{4}\left(\mathrm{H}_{2} \mathrm{O}\right)_{14}\right]\left[\mathrm{Ni}\left(\mathrm{H}_{2} \mathrm{O}\right)_{6}\right]\left[\mathrm{V}_{10} \mathrm{O}_{28}\right] \cdot 3 \mathrm{H}_{2} \mathrm{O}$} & 280960 & $73 c$ \\
\hline Og, Oc & $\mathrm{K}$ & $\left(\left(\mathrm{H}_{2} \mathrm{O}\right)_{2} \mathrm{~K}\left(\mathrm{H}_{2} \mathrm{O}\right)_{3} \mathrm{Co}\left(\mathrm{H}_{2} \mathrm{O}\right)_{3}\right)_{2}\left[\mathrm{~V}_{10} \mathrm{O}_{28}\right]$ & 410930 & $73 \mathrm{~d}$ \\
\hline Of & $\mathrm{K}$ & $\mathrm{K}_{2} \mathrm{Ba}_{2}\left[\mathrm{~V}_{10} \mathrm{O}_{28}\right] .8 \mathrm{H}_{2} \mathrm{O}$ & 88871 & $73 \mathrm{e}$ \\
\hline Of,Og & $\mathrm{Na}$ & $\mathrm{Na}_{6}\left[\mathrm{~V}_{10} \mathrm{O}_{28}\right] \cdot 12 \mathrm{H}_{2} \mathrm{O}$ & 066807 & $73 \mathrm{f}$ \\
\hline Of,Og & $\mathrm{K}$ & $\mathrm{K}_{2} \mathrm{Mg}_{2}\left[\mathrm{~V}_{10} \mathrm{O}_{28}\right] \cdot 16 \mathrm{H}_{2} \mathrm{O}$ & 105264 & $73 \mathrm{~g}$ \\
\hline Of & $\mathrm{Na}$ & $\mathrm{Na}_{6}\left[\mathrm{~V}_{10} \mathrm{O}_{28}\right] \cdot 18 \mathrm{H}_{2} \mathrm{O}$ & 014079 & $73 \mathrm{~h}$ \\
\hline Of & $\mathrm{Ca}$ & $\mathrm{Ca}_{3}\left[\mathrm{~V}_{10} \mathrm{O}_{28}\right] \cdot 16 \mathrm{H}_{2} \mathrm{O}$ & 014309 & $73 \mathrm{i}$ \\
\hline Of, $\mathbf{O g}$ & $\mathrm{K}$ & $\mathrm{K}_{2} \mathrm{Zn}_{2}\left[\mathrm{~V}_{10} \mathrm{O}_{28}\right] \cdot 16 \mathrm{H}_{2} \mathrm{O}$ & 27439 & $73 \mathrm{j}$ \\
\hline \multicolumn{5}{|c|}{ Protein structure with decavanadate } \\
\hline & & Acid phosphatase A & 2d1g & 71 \\
\hline & & Tyrosine kinase & 3gqi & 72 \\
\hline
\end{tabular}


Table 2.

\begin{tabular}{|c|c|c|c|c|c|c|}
\hline & \multicolumn{3}{|c|}{ 2d1g } & \multicolumn{3}{|c|}{ 3gqi } \\
\hline & $\begin{array}{c}\text { Oxygen } \\
\text { type }\end{array}$ & $\begin{array}{c}\text { Amino } \\
\text { acid }\end{array}$ & d(D...O) $(\AA)$ & $\begin{array}{c}\text { Oxygen } \\
\text { type }\end{array}$ & Amino acid & d(D...O) (A) \\
\hline \multirow{13}{*}{ NH...O } & $\mathrm{Oc}$ & HIS & 2.44 & $\mathrm{Ob}$ & ASN & 2.62 \\
\hline & $\mathrm{Oe}$ & HIS & 2.61 & Of & ASN & 2.97 \\
\hline & $\mathrm{Ob}$ & HIS & 2.65 & $\mathrm{Og}$ & ARG & 3.06 \\
\hline & $\mathrm{Oc}$ & ASN & 2.70 & $\mathrm{Oc}$ & ASN & 3.08 \\
\hline & $\mathrm{Oc}$ & HIS & 2.81 & $\mathrm{Og}$ & ASN & 3.13 \\
\hline & $\mathrm{Oe}$ & $\mathrm{ASN}$ & 2.87 & $\mathrm{Oc}$ & ARG & 3.15 \\
\hline & $\mathrm{Oc}$ & HIS & 2.94 & $\mathrm{Oc}$ & ASN & 3.23 \\
\hline & Of & LYS & 2.95 & & & \\
\hline & $\mathrm{Og}$ & HIS & 2.98 & & & \\
\hline & Of & LYS & 3.02 & & & \\
\hline & $\mathrm{Oe}$ & HIS & 3.10 & & & \\
\hline & $\mathrm{Oc}$ & $\mathrm{ASN}$ & 3.11 & & & \\
\hline & $\mathrm{Og}$ & HIS & 3.14 & & & \\
\hline OH...O & Of & & 2.86 & $\mathrm{Od}$ & ASP & 3.08 \\
\hline \multirow{7}{*}{ СН...O } & $\mathrm{Oe}$ & HIS & 2.94 & & & \\
\hline & $\mathrm{Oc}$ & HIS & 2.94 & & & \\
\hline & $\mathrm{Oc}$ & LYS & 2.94 & & & \\
\hline & $\mathrm{Oc}$ & HIS & 3.01 & & & \\
\hline & $\mathrm{Og}$ & HIS & 3.10 & & & \\
\hline & $\mathrm{Og}$ & HIS & 3.10 & & & \\
\hline & $\mathrm{Oc}$ & HIS & 3.20 & & & \\
\hline
\end{tabular}


